\title{
Use of petrological and organic geochemical data in determining hydrocarbon generation potential of coals: miocene coals of Malatya Basin (Eastern Anatolia-Turkey)
}

\author{
Nazan Yalcin Erik ${ }^{1}$ (i) Faruk $^{A y^{2}}$
}

Received: 5 March 2020/Revised: 5 August 2020/Accepted: 16 October 2020/Published online: 21 November 2020

(C) The Author(s) 2020

\begin{abstract}
With this study, the hydrocarbon generation potential of Miocene aged coals around Arguvan-Parçikan in the northern district of Malatya province was evaluated with the aid of petrological and organic geochemical data. According to organic petrography, coal quality data, and low thermal maturity, the Arguvan-Parçikan coals are of high-ash, highsulfur subbituminous $\mathrm{B} / \mathrm{C}$ rank. The organic fraction of the coals is mostly comprised of humic group macerals, with small percentages derived from the inertinite and liptinite groups. The mineral matter of the coals is comprised mainly of calcite and clay minerals. The total organic carbon (TOC, wt $\%$ ) values of the shale and coal samples are between $2.61 \mathrm{wt} \%$ and $43.02 \mathrm{wt} \%$, and the hydrogen index values are between 73 and $229 \mathrm{mg} \mathrm{HC} / \mathrm{g}$ TOC. Pyrolysis $\left(T_{\max }, \mathrm{PI}\right)$, huminite/vitrinite reflectance $\left(R_{\mathrm{o}}, \%\right)$, and biomarker ratios $\left(\mathrm{CPI}, \mathrm{Pr} / \mathrm{Ph}\right.$ ratio, $T \mathrm{~s} /(T \mathrm{~s}+T \mathrm{~m})$ ratio, $\mathrm{C}_{32}$ homohopane ratio $(22 \mathrm{~S} / 22 \mathrm{~S}+22 \mathrm{R})$ and $\mathrm{C}_{29} \beta \beta /(\beta \beta+\alpha \alpha$ sterane ratio) indicate that the organic matter of the studied coals is thermally immature. When all these data are taken together, Miocene aged coals around Arguvan are suitable for hydrocarbon generation, especially gas, in terms of organic matter type (Type III and Type II/III mixed), organic matter amount ( $>10 \mathrm{wt} \% \mathrm{TOC}$ ), however, low liptinitic macerals $(<15 \%-20 \%)$, low hydrogen index $(<200 \mathrm{mg} \mathrm{HC} / \mathrm{g} \mathrm{TOC})$ and low thermal maturity values inhibit the hyrocarbon generation.
\end{abstract}

Keywords Arguvan $\cdot$ Malatya basin $\cdot$ Eastern Anatolia $\cdot$ Organic geochemistry $\cdot$ Organic petrography $\cdot$ Miocene coal

\section{Introduction}

Energy is one of the most fundamental and driving needs of the countries' social and economic development, and the concepts of "energy security" and "sustainable energy" are the main support for the stability of economic life and for ensuring national security in a global or regional significance. Although the energy consumed in the world today is derived from different sources, fossil fuels (oil, coal and natural gas) have the largest share in these

Nazan Yalcin Erik

nyalcin@cumhuriyet.edu.tr

1 Department of Geological Engineering, Cumhuriyet University, 58140 Sivas, Turkey

2 Department of Anthropology, Cumhuriyet University, 58140 Sivas, Turkey resources, accounting for nearly 87\% (TP Energy Report 2015) of all the sources. Turkey, though quite poor in terms of oil reserves, has different coal reserves in all its geographical regions, notably in Western Anatolia (Tuncalı et al. 2002). However, approximately $68 \%$ of the lignite/sub-bituminous coal in Turkey are of low calorific value (nearly $<1500-2000 \mathrm{kcal} / \mathrm{kg}$ ) (Palmer et al. 2002; Tuncal1 et al. 2002).

In Turkey, for which coal is so important in terms of meeting the energy needs, this resource needs to be reevaluated in accordance with the industrial and energy sector development in the world as well as industrial and economic scope. In particular, the suitability of coals for liquefaction and gasification processes or the determination of their coal-derived hydrocarbon potential are important issues. Few geological studies have been carried out on the Tertiary coals of Anatolia (Artova, Zile-Tokat, Hafik- 
Sivas; Çayırl1-Erzincan, Oltu-Erzurum; Soma-Manisa; and Şarkikaraağaç-Isparta), and thus a limited number of and organic geochemical and petrographic evaluation has been made (Yalçın Erik and Sancar 2010; Hoş Çebi and Korkmaz 2013; Yalçın Erik and Ay 2013; Kara Gülbay 2015; Ünal et al. 2014; Hökerek and Özçelik 2015; Bechtel et al. 2016; Ünal and Özçelik 2017).

Although some geological and stratigraphic investigations have been made concerning the coals around Arguvan-Parçikan (Malatya) which are the subject of this study (Yoldaş 1972; Sun 1987; İçel 1988; Türkmen and Aksoy 1998; Erdoğan 2004; Türkmen et al. 2004; Koç-Taşgın 2011; Booth et al. 2014), there is not any study on the evaluation of petrology, organic geochemistry and hydrocarbon generation potentials.

This study focuses on the Miocene Arguvan-Parçikan (Malatya) coal bearing units located in the East Anatolian Fault Zone (EAFZ), Eastern Anatolia, Turkey. The principal aim of the study is to determine factors that control coalification environment and hydrocarbon generation potentials by means of bulk coal analyses (proximate-ultimate), mineralogical composition, coal petrography, and organic geochemistry.

\section{Geological and stratigraphic properties}

\subsection{Regional geology}

The formation of Central Anatolian basins between the two continental units, Sakarya continent and Kurşehir Massif, with the closure of the northern branch of Neo-Tethysin in the Cretaceous-Eocene time period is very important for the regional geological evolution of Turkey, (Şengör and Yılmaz 1981; Görür et al. 1998) (Fig. 1a, b). These basins, which indicate the paleotectonic period, are divided into two groups as magmatic arc (pre-arc and intra-arc) and collision-related interior basins (Görür et al. 1998). Malatya Basin, included in the study area, is the continuation of Hekimhan Basin and started to form in Late Cretaceous (Okay and Tüysüz 1999). The collision of Anatolian and Arabian plates during the Early Miocene completed its evolution with the closure of the Neo-Tethys. The coexistence of Neogene continental expansion and strike-slip tectonic movement in Eastern Anatolia caused the formation of limited intermountain basins such as Malatya Basin (Görür et al. 1998). Gravity tectonics in the study area are represented by growth faults that began in the early Miocene, and an anticlinal found in Middle Eocene sediments, and the Malatya fault, which cuts the Malatya Basin, with a NE-SW direction, with a left-directional pulse, and the rupture faults that cut the southern growth fault of the basin are structural elements that express neo-tectonic movements. (Okay and Tüysüz 1999; Önal 2009; Türkmen et al. 2004). This fault-controlled basin is an area where active tectonic activities still continue nowadays (The latest important earthquake occurred in the magnitude of 5.3 around Malatya-Elazığ on 24 January 2020). As a result of displacements between Eastern Anatolia Fault Zone (EAFZ) and Pliocene and Early Pleistocene, fluvial and lacustrine sediments occurred in these basins. There are also small economic coal deposits and/or coal layers as part of the basin development (Tuncalı et al. 2002; Türkmen et al. 2004; Önal 2009).

\subsection{Stratigraphy}

Stratigraphic sequence of the study area consists mainly of Paleozoic and Cenozoic aged sedimentary rocks and volcanics (Figs. 2a, 3). Paleozoic aged limestones are dark blue gray colored, medium-thick bedded limestones and calcschists. The Cenozoic sequence starts with Eocene series and is considered to be two lithostratigraphic units, Eocene (Lutetian) conglomerate and Limestone-Shale
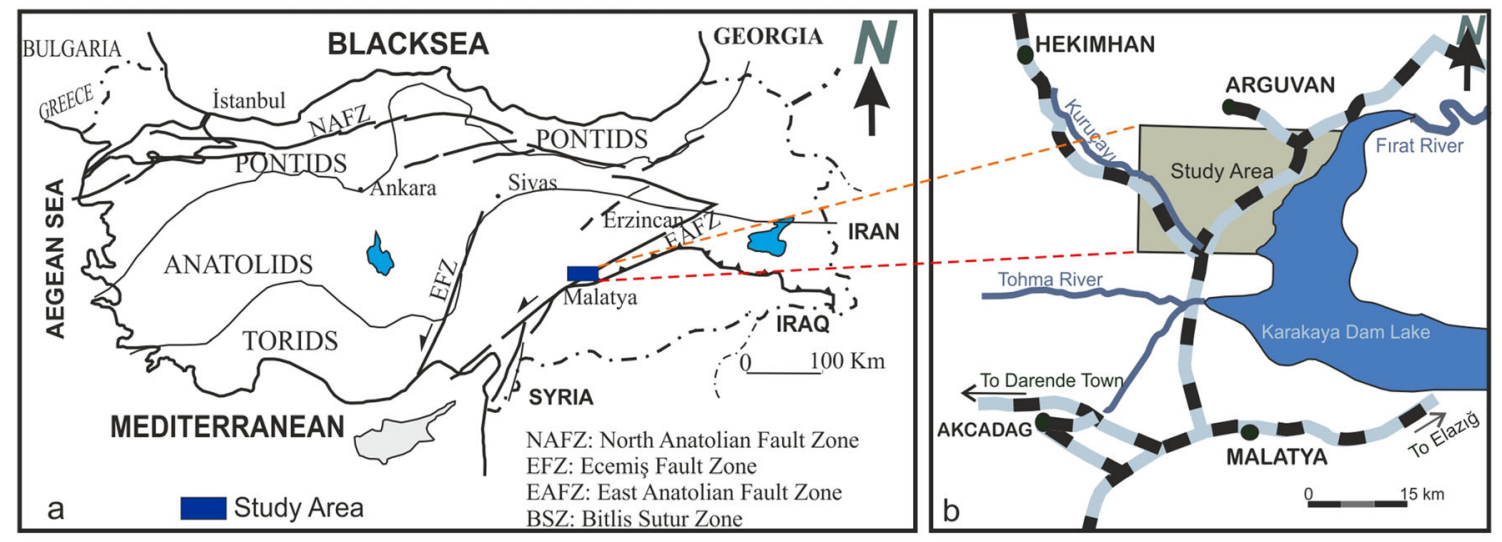

Fig. 1 a Turkey's place in the tectonic units of the study area, b location map of investigated area 


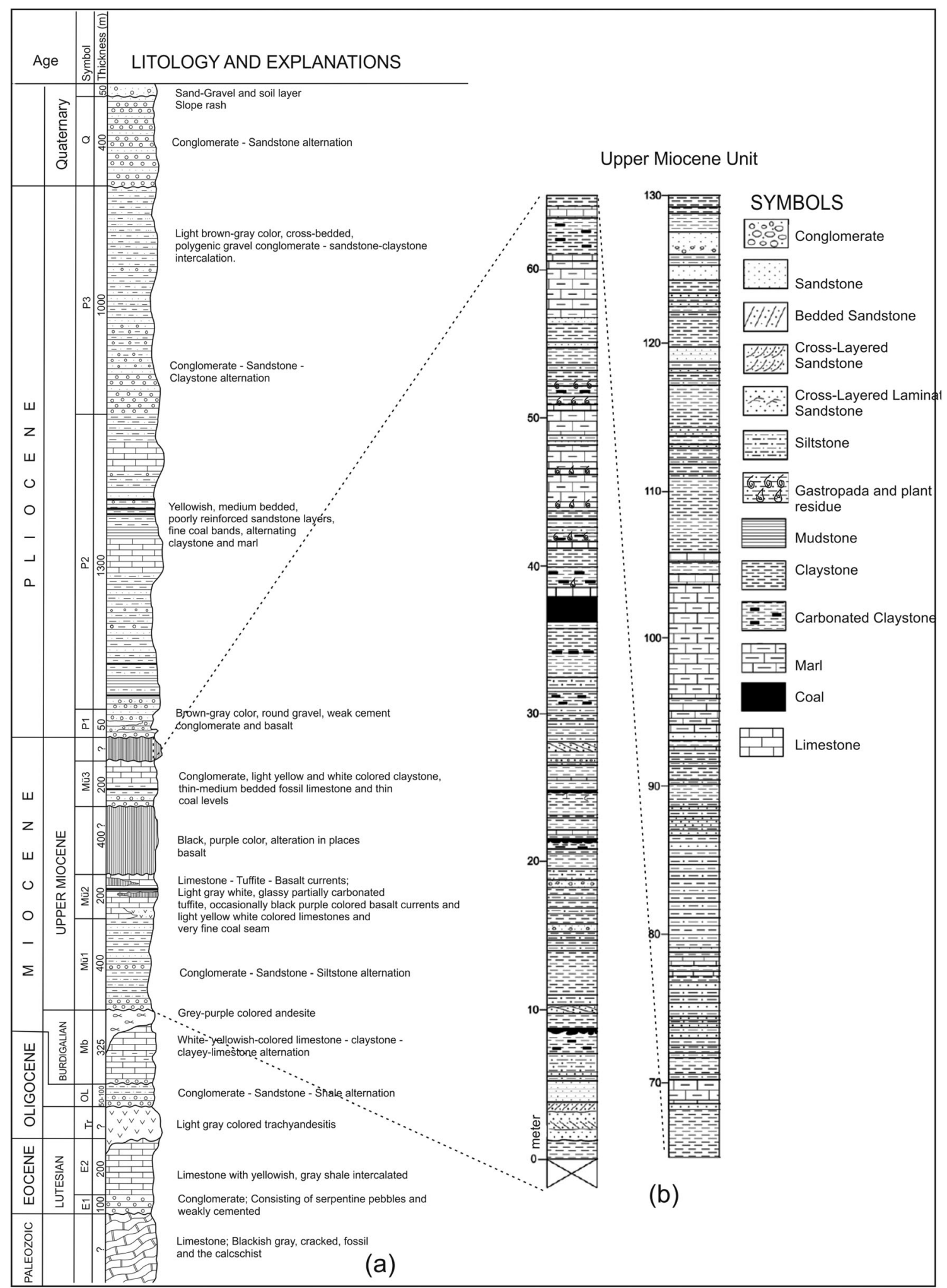

Fig. 2 a Stratigraphic columnar section of investigated area ( modified from İçel 1988), b Columnar sections of Parçikan coal bearing units (modified from Koç-Taşgın 2011)

(Figs. 2a, 3) (İçel 1988). The polygenic conglomerates forming the base of the Eocene are approximately $100 \mathrm{~m}$ thick and consist of thick-bedded, brown colored, tightly cemented conglomerates (Fig. 2a). 


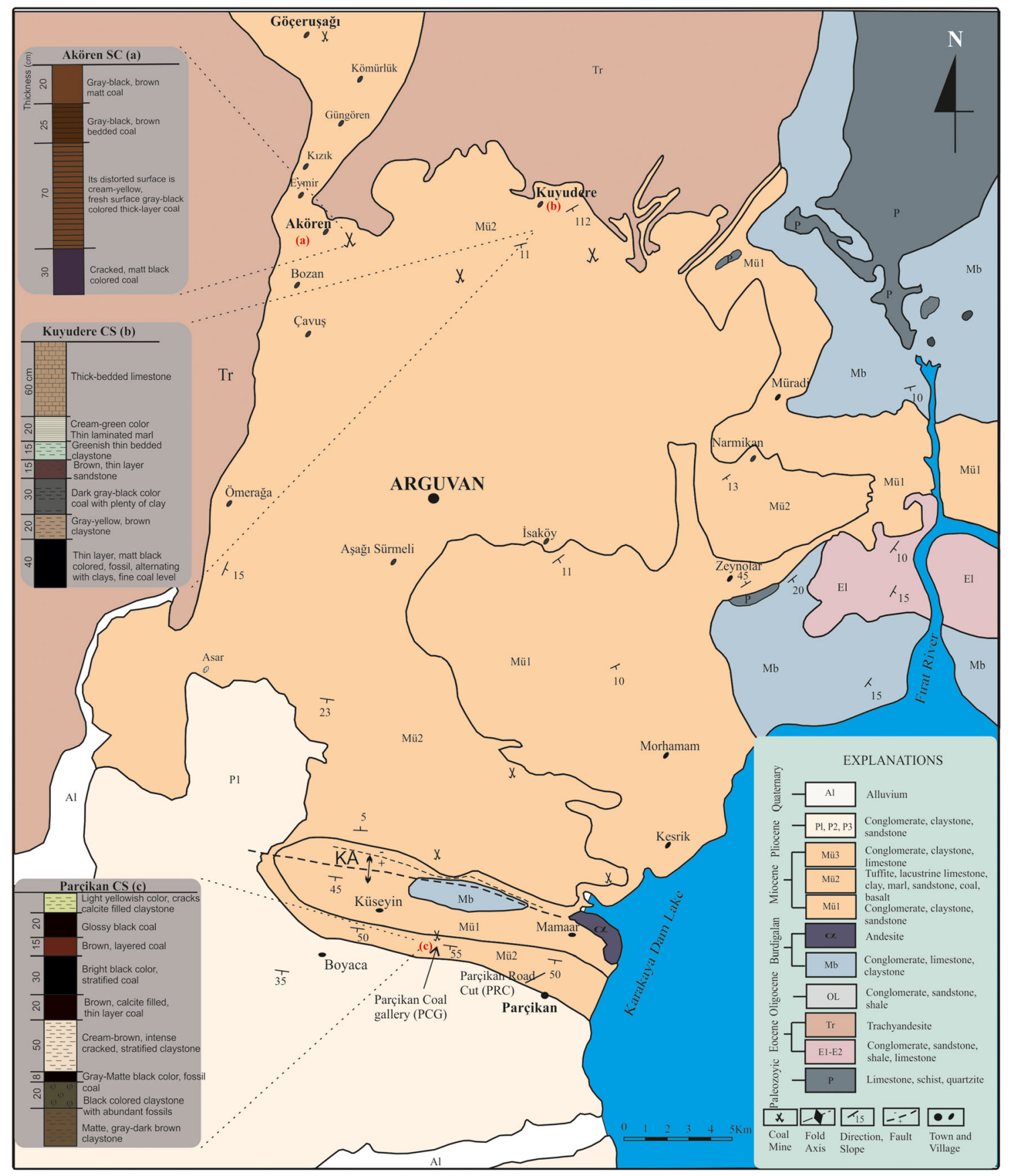

Fig. 3 Simplified geological map of investigated area and columnar sections of coaly areas

In the limestone-shale alternation, the limestones are yellow-light brown colored and highly fossiliferous. Oligocene aged unit, which is red, gray-green colored, generally consists of conglomerate-sandstone-shale intercalation, and the thickness is around $50-100 \mathrm{~m}$ (Figs. 2a, 3) (İçel 1988). The Burdigalian aged unit consists of red claystone, mudstone, siltstone-mudstone intercalation with coal levels, limestone and marls (Türkmen et al. 2004). This unit, which shows lateral and vertical transitions with Malatya volcanic, gives a sample in the
Karaca Anticline (KA) core in the south (Fig. 3). It was described as the Alibonca Formation by Önal (2009). Volcanic rocks in the study area consist mainly of trachyandesite, andesite and basalts. The Late Miocene series with a lacustrine character consists of three levels: Mü1 (Conglomerate-Sandstone-Claystone), Mü2 (LimestoneTuffite-Basalt Currents, coal layers), Mü3 (ConglomerateLimestone-Claystone-coal layer) (Figs. 2a, 3) (İçel 1988).

Marl-Clayey Limestone-Claystone-Lignite (P2) The unit defined as Boyaca Formation by Önal (2009) is composed 
of clayey limestone-marl-claystone intercalations, and gravelly sandstone and coal bands are found occasionally. Conglomerate-Sandstone-Claystone (P3), which begins with conglomerates composed of distinctly layered basalt and limestone pebbles, and intercalation with sandstones continues approximately $1000 \mathrm{~m}$, is very well rounded, (İçel1988). Quaternary aged units are comprised of conglomerate and alluviums and unconformably overlie all units (Fig. 2a) (İçel 1988).

\section{Analysis methods}

The properties of the coals in the study area (thickness, distribution area, lithotype changes and tectonic effects) were evaluated by field surveys and compared with other coal occurences in this basin. Thin coal veins are seen around Arguvan, mainly around Parçikan, Kuyudere, Göçeruşağ1 and Akören villages (Fig. 3). However, the only economically operating site is the Parçikan coal field. As the coal vein in this area is relatively thick $(2 \mathrm{~m})$ and the relationship between the floor and overlying rocks is more clearly seen, detailed investigations and sampling were made in the vicinity of Parçikan village (in the Arguvan-Parçikan road cut-Fig. 4a, d and Parçikan coal mining gallery-Fig. 4b).

Six channel samples of coal and other organic rich mudstones, coaly shales from all investigated areas were collected according to ASTM D-2234 and used for this study. A systematic sampling based on variation in lateral and vertical succession of the sedimentary facies was carried out. The samples were taken at about $1 \mathrm{~m}$ interval vertically after removing weathered surfaces. Lithological features of each of the studied coal sections (Fig. 4a-c) were macroscopically described and the lignite lithotype was determined according to guidelines established by the International Committee for Coal and Organic Petrology (ICCP 1994), as well as by Taylor et al. 1998.

Leitz MPV-SP reflective light microscope and 50X objective were used for petrographic evaluations. Leica DM2500 P and MSP200 windows-based program were used for random huminite/vitrinite reflection measurements and they were evaluated according to ICCP (1998), ISO 11760 (2005). Random reflectance measurements were performed using the Zeiss RS-III microscope with $40 \times$ oil immersion objective according to ISO 7404-5 (2009) standards, and results have been presented as mean random reflectance values $\left(R_{\mathrm{o}}, \%\right)$. The GI, TPI, WI, and GWI parameters were determined according to the formulas prepared for Tertiary aged lignites, by Kalaitzidis et al. (2004). The maceral nomenclature was based on the ICCP System1994 (ICCP 2001; Sýkorová et al. 2005; Pickel et al. 2017).
The standart proximate and ultimate analyses of the coal samples were conducted according to ASTM standards (ASTM D3174, 2004; D3302, 2004; D5373, 2004) in M.T.A. The analyses were carried out in the laboratories of the General Directorate of Mineral Research and Exploration MAT Department (MTA, Ankara). The gross and net calorific values of coal samples were determined using an IKA 4000 adiabatic calorimeter (ASTM D5865, 2004); also, sulfur, carbon, hydrogen and nitrogen contents were determined with LECO TGA 701 analyzer in the same laboratory.

Mineralogical composition was determined in the 28 powder coal samples and their clay fractions $(\varnothing<2 \mathrm{~lm})$ using X-ray diffraction spectrometers with $\mathrm{CuKa}$ radiation (4-70 $2 \mathrm{H}$ range in powder-samples and $0-302 \mathrm{H}$ range in clay-fractions) in the laboratories at Cumhuriyet University (Sivas) and the General Directorate of Mineral Research and Exploration (MTA, Ankara).

Rock-Eval/TOC analysis was made for ten coal and coaly shale samples that were collected systematically from measured sections in the Arguvan-Parçikan coal areas (Figs. 2b, 3). These analyses of all the samples were made using a Rock-Eval 6 instrument equipped with a TOC module. The samples were heated from $300{ }^{\circ} \mathrm{C}$ (hold time $3 \mathrm{~min}$ ) to $650{ }^{\circ} \mathrm{C}$ at a rate of $25^{\circ} \mathrm{C} / \mathrm{min}$. Using the TOC and Rock-Eval pyrolysis results as a basis for selection, ten samples were extracted in ASE 300 with Dichloromethane $\left(\mathrm{CH}_{2} \mathrm{Cl}_{2}\right)$ for approximately $40 \mathrm{~h}$ in the TP AR-GE laboratory (Ankara). The whole extract was analyzed using an Agilent 6850 gas chromatograph equipped with a flame photometric detector and flame ionization detector. In addition, saturated portions were analyzed by Agilent 7890A/5975 ${ }^{\circ} \mathrm{C}$ GC-MS, terpane and sterane molecules were studied in SIM Scan mode using 191 and $217 \mathrm{~m} / \mathrm{z}$ ratios, respectively (TP AR-GE Lab., Ankara).

\section{Results and discussion}

\subsection{Coal geology investigations and macroscopic description}

The investigated coals are found in the Upper Miocene units around the villages of Parçikan, Akören, Göçeruşağ and Kuyudere within the borders of Arguvan district (Figs. 2a-c, 4a-d). In the section (PCS; Figs. 2c, 4a) measured in the south side of the Karaca Anticline (KA), the thickness of the coal seam was determined to be around $1.85 \mathrm{~m}$ (Figs. 2c, 4a) but $2 \mathrm{~m}$ in the Parçikan coal gallery (Fig. 4b). Due to the relatively thick coal levels in the Parçikan region, a private coal company continues its mining operation for local needs. At the upper levels of the coal unit on the Arguvan-Parçikan road cut (PRC), there 

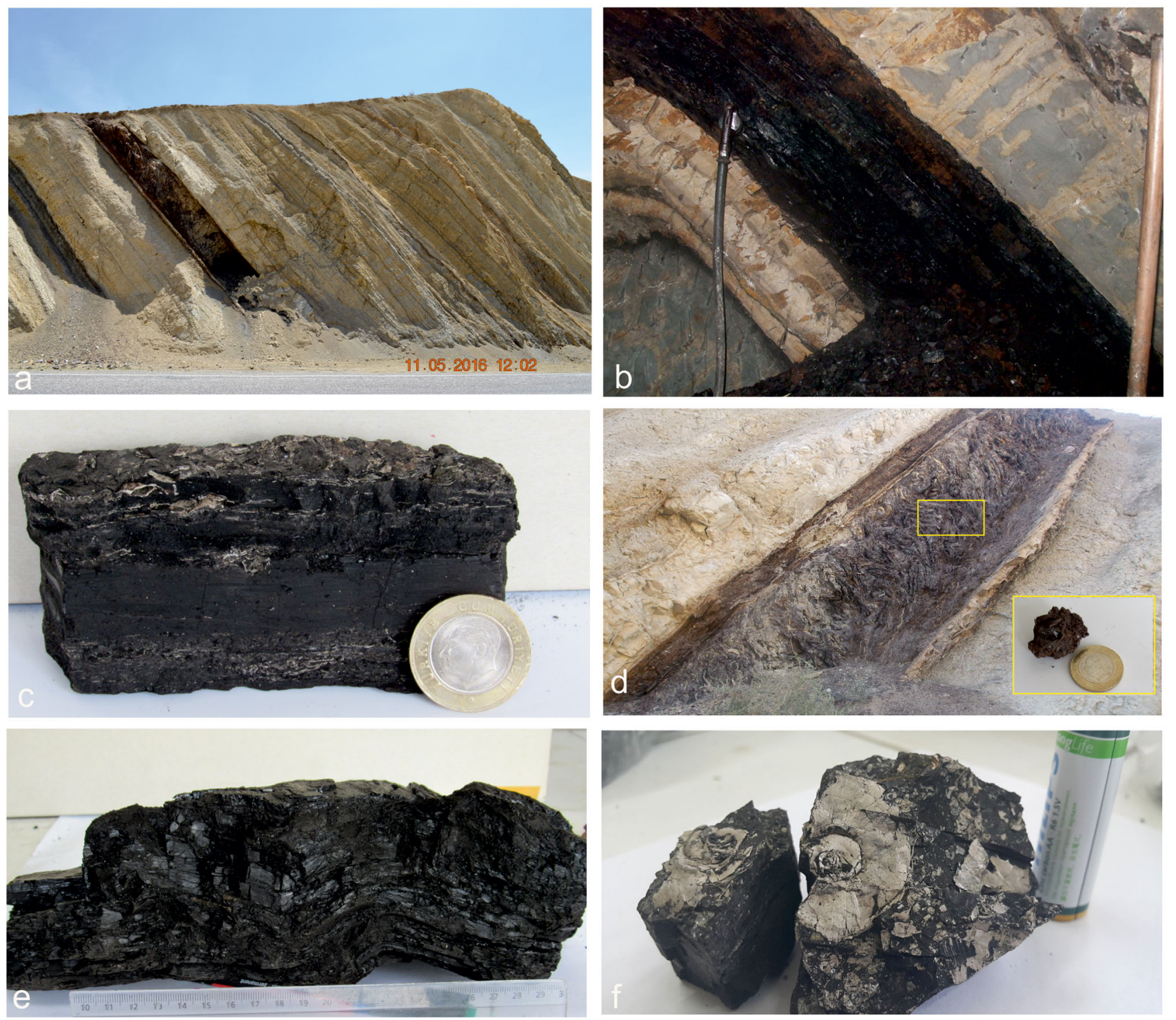

Fig. 4 Field views and some structural features of the coal in the study area. a The upper levels of the coal unit on the Arguvan-Parçikan road cut, $\mathbf{b}$ the view of the coal seam and side rocks in the coal mine gallery, $\mathbf{c}$, e soft sediment deformation structure and macroscopic view of the studied coal, $\mathbf{d}$ Clayey coal levels showing soft sediment deformation under the influence of active tectonic movements $\mathbf{f}$ macroscopically, the coal section displaying blackish colour is dull and brittle, and contains gastropod shells at certain place

are bright, brittle coals about $30 \mathrm{~cm}$ thick (Fig. 4c, e). Macroscopically, the coal section displaying blackish colour is dull and brittle, and contains gastropod shells at certain places (Fig. 4f).

Clayey coal levels showing soft sediment deformation under the influence of active tectonic movements are present below this level (Fig. 4e). There are abundant fossiliferous, clayey limestones particularly on the floor and ceiling of the thick coal vein. Black colored very fossiliferous claystones with $8 \mathrm{~cm}$ thickness and gray-black colored fossiliferous coal levels are observed on matt, graydark brown colored claystones. Approximately $50 \mathrm{~cm}$ of cream colored, occasionally dark brown, claystones with abundant-cracks are followed by the main coal vein. At the base of this vein is a $20 \mathrm{~cm}$ brown, calcite filled thin coal layer followed by a bright black colored $30 \mathrm{~cm}$ coal vein and $15 \mathrm{~cm}$ brown colored, mostly clayey coals. The side rocks of the coal vein are composed of gray-dark yellow, brownish-green colored clayey and carbonated parts and alteration structures are intensely observed in places (Fig. 4a, d).

Coals around Akören village are seen as alternation of black, dark brown color, mostly calcite and claystone. The lower parts of the coal vein are matt black, with abundant cracks; medium levels are creamy-yellowish black, hard and layered, the top layer of coal is cracked and matt black 
Table 1 Proximate analysis data of investigated samples

\begin{tabular}{|c|c|c|c|c|c|c|c|c|}
\hline $\begin{array}{l}\text { Coal } \\
\text { section }\end{array}$ & $\begin{array}{l}\text { Sample } \\
\text { number }\end{array}$ & $\begin{array}{l}\text { Sample } \\
\text { type }\end{array}$ & $\begin{array}{l}\text { Total moisture } \\
(\mathrm{wt} \%)\end{array}$ & $\begin{array}{l}\text { Ash } \\
(w t \%, d b)\end{array}$ & $\begin{array}{l}\text { Volatile matter } \\
(\mathrm{wt} \%, \mathrm{db})\end{array}$ & $\begin{array}{l}\text { Fixed } \\
\text { carbon }\end{array}$ & $\begin{array}{l}\text { Net calorific value } \\
(\mathrm{kcal} / \mathrm{kg})\end{array}$ & $\begin{array}{l}\text { Gross calorific value } \\
(\mathrm{kcal} / \mathrm{kg})\end{array}$ \\
\hline \multirow[t]{4}{*}{ Parçikan } & \multirow[t]{2}{*}{ P06 } & Original & 21.50 & 50.95 & 18.34 & 11.03 & 1394 & 1591 \\
\hline & & Dry & - & 69.90 & 23.36 & 14.56 & 1936 & 2027 \\
\hline & \multirow[t]{2}{*}{ P11 } & Original & 27.74 & 46.55 & 20.15 & 18.14 & 694 & 912 \\
\hline & & Dry & - & 64.42 & 27.89 & 21.09 & 1184 & 1282 \\
\hline \multirow[t]{2}{*}{ Göçeruşağ1 } & \multirow[t]{2}{*}{ GC-1 } & Original & 20.99 & 73.36 & 4.39 & 8.35 & \multirow{2}{*}{\multicolumn{2}{|c|}{$\begin{array}{l}\text { This analysis value could not be } \\
\text { determined because the sample was not } \\
\text { burned }\end{array}$}} \\
\hline & & Dry & - & 92.85 & 5.56 & 6.91 & & \\
\hline \multirow[t]{5}{*}{ Akören } & \multirow[t]{2}{*}{ A-03 } & Original & 29.65 & 62.69 & 6.84 & 13.74 & 28 & 224 \\
\hline & & Dry & - & 89.12 & 9.72 & 16.25 & 286 & 318 \\
\hline & \multirow[t]{3}{*}{ Akb-2 } & Original & 22.08 & 68.37 & 8.37 & 10.64 & 137 & 294 \\
\hline & & Dry & - & 87.74 & 10.74 & 6.48 & 342 & 377 \\
\hline & & \multicolumn{5}{|c|}{ ASTM D7582 } & \multicolumn{2}{|l|}{ ASTM D 5865} \\
\hline
\end{tabular}

and $145 \mathrm{~cm}$ thick (Fig. 4a). The coal bearing section around Kuyudere village is approximately $200 \mathrm{~cm}$ thick and has a matt black and brown color, mostly carbonate host rock, clayey, and it has abundant cracks. Above the coal layer, there are abundant fractured and brittle claystones, and at the top are layered limestones (Fig. 4b). It is observed that coal layer thicknesses are around 30-40 cm and some carbonated and clayey levels are frequently intercalations. In the coal sample observed around the Göcerusag1, generally there are "mixed" levels with soil cover, irregular "thickness and diffuse", and dense clayey layers. There are coal levels with an approximate thickness of $195 \mathrm{~cm}$. It was found that the matte black and brown coals, although the layer is difficult to follow, $0.3-0.85 \mathrm{~cm}$ thick coal layer, are mostly carbonate host rock and claystone intercalation due to the presence of a cover layer and a thin soil layer.

\subsection{Mineralogical compositions}

The coal bearing units in the studied areas are mainly composed of coal, organic-rich carbonated rock, coaly claystones and clayey levels (Figs. 2b, 4a, b, d). The investigated samples contain a variety of minerals at variable proportions. Identifiable mineral constituents include pyrite, quartz, clay minerals, calcite, and jarosite (Fig. 4d). The dominant component is carbonates (calcite; $4 \mathrm{wt} \%-96 \mathrm{wt} \%$; dolomite; $7 \mathrm{wt} \%$ ) and clay (11 wt $\%-82$ $\mathrm{wt} \%$ ) in the mineralogical composition of the studied samples. In addition, sulphides (framboidal pyrite and cavity fillings; $4 \mathrm{wt} \%-7 \mathrm{wt} \%$ ), quartz $3 \mathrm{wt} \%-48 \mathrm{wt} \%$, feldspar $5 \mathrm{wt} \%-46 \mathrm{wt} \%$ are other minerals in the composition. The predominance of silicate minerals along with the high ash yields implies that the clastic input was high during peat depositions. The clay minerals are mostly aggregated with other clastic minerals (e.g., quartz, feldspars) and attrinite as well. Clay minerals determined by XRD-clay fraction diffractograms are illite (12 wt $\%-76$ wt $\%)$, smectite (21 wt $\%-63 \mathrm{wt} \%)$ and chlorite (11 wt $\%-75$ wt $\%)$. Framboidal pyrite crystals are common in the studied samples, whereas massive pyrite crystals are barely identified.

\subsection{Proximate and ultimate analyses}

Table 1 summarizes the results of proximate and ultimate analyses along with net calorific values of the investigated coal samples. The high ash yield of the samples on an air dry basis varies between $64.42 \%$ and $92.85 \%$ (av. 80.81\%), total sulfur $0.02 \%-3.73 \%$ (av. $1.46 \%$ ); the total moisture was determined as $20.99 \%-29.65 \%$ (av. $28.69 \%$ ) as well as low net calorific values (Table 1). The ultimate analysis shows that the coal samples are characterized by moderate hydrogen (up to $1.67 \%$, on an air dry basis) contents (Tables 1 and 2). Carbon values on dry basis were between $12.63 \%$ and $65.53 \%$ (av; $43.41 \%$ on an air-dry basis), hydrogen $4.18 \%-7.06 \%$ (av. $5.53 \%$ on an air-dry basis), nitrogen $0.13 \%-2.07 \%$ av. $1.23 \%$ (on an air-dry basis), $\mathrm{H} / \mathrm{C}$ ratios vary between 0.91 and 6.71 and $\mathrm{O} / \mathrm{C}$ ratios range between 0.06 and 0.90 (Table 2).

The gross calorific value varies between 318 and $2027 \mathrm{kcal} / \mathrm{kg}$ (av. $1001 \mathrm{kcal} / \mathrm{kg}$ ), and the volatile matter yield is between $5.56 \%$ and $27.89 \%$ (av. 15.45\%). $1282-2027 \mathrm{kcal} / \mathrm{kg}$ values were determined only from the hand piking samples taken from the coal bands operated in the Parçikan coal field. The calorie, total sulfur and fixed carbon values of the samples in the other sites were lower and the ash yields were higher in comparison with the Parçikan coal area samples (Table 1). 
Table 2 Ultimate analysis data of investigated samples

\begin{tabular}{|c|c|c|c|c|c|c|c|c|c|c|}
\hline Coal section & Sample number & Sample type & $\mathrm{C}$ & $\mathrm{H}$ & $\mathrm{N}$ & $\mathrm{O}$ & S & $\mathrm{H} / \mathrm{C}$ & $\mathrm{O} / \mathrm{C}$ & $\mathrm{N} / \mathrm{C}$ \\
\hline \multirow[t]{6}{*}{ Parçikan } & \multirow[t]{3}{*}{ P-06 } & Original & 18.06 & 1.38 & 0.57 & 5.91 & 2.93 & & & \\
\hline & & Dry in the air & 21.90 & 1.67 & 0.69 & 6.38 & 3.73 & & & \\
\hline & & Dry ash free & 65.53 & 4.99 & 2.07 & 19.08 & 1.58 & 0.91 & 0.22 & $\mathbf{0 . 0 3}$ \\
\hline & \multirow[t]{3}{*}{ P-11 } & Original & 13.22 & 1.07 & 0.53 & 11.81 & 2.18 & & & \\
\hline & & Dry in the air & 17.25 & 1.40 & 0.70 & 12.73 & 0.02 & & & \\
\hline & & Dry ash free & 51.41 & 4.18 & 2.07 & 37.95 & 0.02 & 0.98 & 0.55 & $\mathbf{0 . 0 3}$ \\
\hline \multirow[t]{3}{*}{ Göçeruşağ1 } & \multirow[t]{3}{*}{ GC-1 } & Original & 0.71 & 0.40 & 0.01 & 5.08 & 0.23 & & & \\
\hline & & Dry in the air & 0.85 & 0.47 & 0.01 & 5.47 & 0.33 & & & \\
\hline & & Dry ash free & 12.63 & 7.06 & 0.13 & 81.37 & 0.81 & 6.71 & 0.06 & 0.01 \\
\hline \multirow[t]{6}{*}{ Akören } & \multirow[t]{3}{*}{ A-03 } & Original & 3.31 & 0.43 & 0.09 & 4.97 & 1.04 & & & \\
\hline & & Dry in the air & 4.48 & 0.58 & 0.12 & 5.36 & 2.93 & & & \\
\hline & & Dry ash free & 43.22 & 5.84 & 1.20 & 51.78 & 3.73 & 1.62 & 0.90 & 0.02 \\
\hline & \multirow[t]{3}{*}{ Akb-2 } & Original & 4.23 & 0.53 & 0.06 & 5.01 & 1.58 & & & \\
\hline & & Dry in the air & 5.13 & 0.65 & 0.08 & 5.40 & 2.18 & & & \\
\hline & & Dry ash free & 44.24 & 5.57 & 0.66 & 46.59 & 0.02 & 1.51 & 0.80 & 0.01 \\
\hline
\end{tabular}

\subsection{Petrological properties}

\subsubsection{Lithotype characteristics}

When broken, the sorfaces of the Parçikan coals appear blackish-brown, while the layer is seen to be darker black at some levels. After surface moisture is gone, prismatic cracks and concoidal fractures develop in the coal structure (Fig. 4c, e). The coals in the investigated locations are macroscopically different from each other due to their mainly seam thickness, and physico-chemical degradation processes. Coals in Akören, Göçeruşağı and Kuyudere sections are generally much more clayey; they are seen in the form of very thin bands or lenses and differ from Parçikan coals in macroscopic view. In the field observations of the coals and in the detailed macro examination of the samples in the laboratory, the durain level is clearly monitored with a few mm clarain band with vitrain bands of approximately 5-6 cm thickness (Fig. 4c, e). Plant tissues, fossil shells (gastrapods) and jarocyte minerals, which have remained intact in fine coal seam, have also been found (Fig. 4d, f).

\subsubsection{Microlithotype and maceral composition}

The quantitative distribution of different macerals (on mineral-free basis) and associated mineral matter from the coal samples are shown in Table 3. Representative microphotographs of various macerals are illustrated in Fig. 5.

Petrographic observations reveal that the Arguvan coals are rich in huminite (49 vol\%-67 vol\%, mean; 60.29 vol\%), in which textinite and ulminite (telohuminite subgroup), attrinite, densinite (detrohuminite subgroup), and corpohuminite (gelohuminite subgroup) are more abundant than other macerals. (Table 3 and Fig. 5). The amount of the macerals of the liptinite group is very low (3 vol\%-9 vol\% (av. $5.86 \mathrm{vol} \%$ ), and they are represented by sporinite, resinite suberinite and dominantly liptodetrinite. The color of sporinite in fluorescent light is yellow. Inertinite macerals are rare 1 vol\%-4 vol\% (av. 2.29 vol\%) and represented by fusinite, funginite and inertodetrinite. The inertinite group macerals occur in low concentrations (av. $6.64 \mathrm{vol} \%$ ), and inertodetrinite is the most common maceral of this group (Fig. 5). The distributions of the maseral groups of the studied coal samples in the triangular diagram are given in Fig. 6a, b.

The mineral matter content, as determined microscopically, ranges from 11 vol\% to $42 \mathrm{vol} \%$, and consists mainly of clay minerals, followed by carbonate (calcite), sulphate (gypsum) and iron (pyrite) minerals. The most common occurrence of pyrite in the form of crack and void filling or granular formations observed in the coals is framboidal pyrites and they have an average composition of $3.71 \mathrm{vol} \%$ (Table 3) (Fig. 5). Framboidal pyrite crystals are generally syngenetic and related to reducing conditions within the palaeomire (Kalaitzidis et al. 2004; Siavalas et al. 2009). Although the coal formations around Arguvan appear physically different from each other, there is no an important difference in petrographic composition. Only Akören coals can be said to have more inertodetrinites, except that the maceral composition properties are similar (Table 3). 


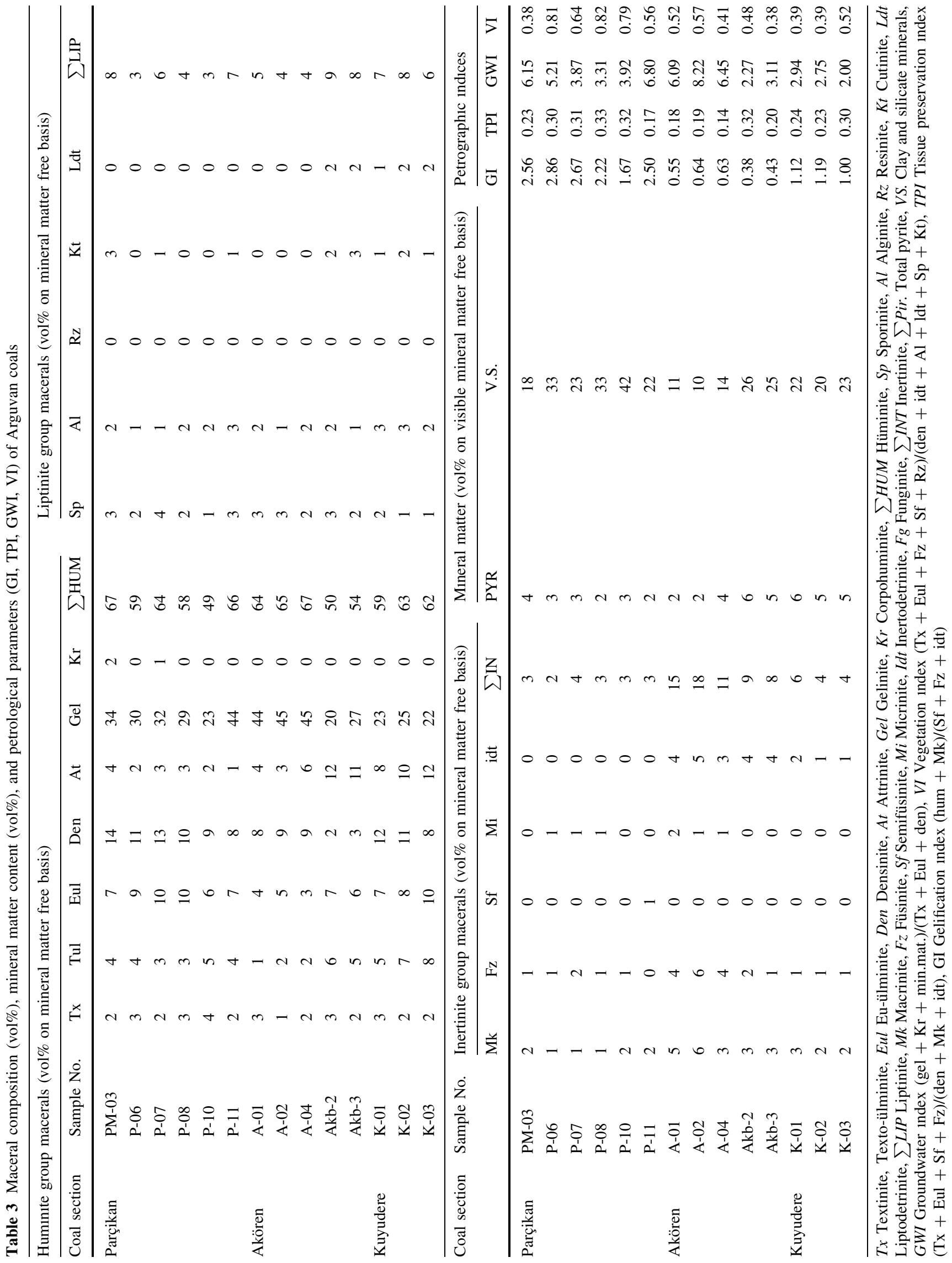




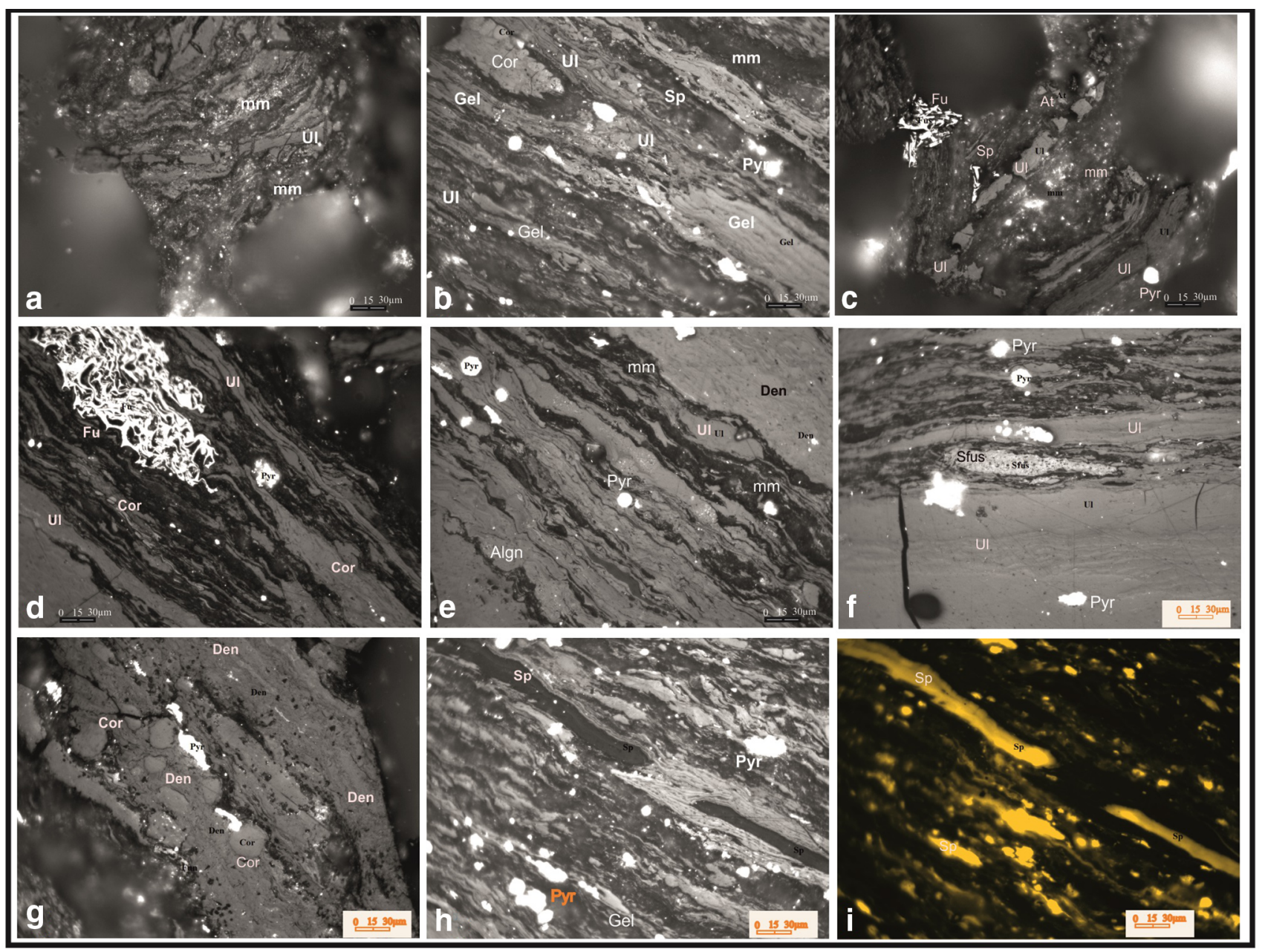

Fig. 5 Representative photomicrographs of macerals of the investigated coals

\subsection{Bulk geochemical characteristics}

Rock-Eval pyrolsis data were interpreted according to Peters (1986) and Lafarqué et al. (1998), on the amount of organic matter, organic matter type (kerogen type), diagenetic process (thermal maturity) and hydrocarbon generation potential of coal and coaly samples taken from the vicinity of Arguvan. Total organic carbon (TOC) values range from $2.61 \mathrm{wt} \%$ to $43.02 \mathrm{wt} \%$. The total organic carbon and hydrogen index values are seen to be higher especially in the Parçikan and Akören area samples (Table 4). Coal samples are characterized by a low hydrogen index (HI $=73-229 \mathrm{mg} \mathrm{HC} / \mathrm{g}$ TOC). $T_{\max }$ values ranging from 409 to $436{ }^{\circ} \mathrm{C}$ agree with the low rank of the coal.

\subsection{Molecular geochemistry reviews}

\subsection{1 n-alkane and isoprenoid compound properties}

The extract values of the investigated samples are generally low (Table 5), higher only in the Parcikan samples (260-5202 ppm; av.: 2294 ppm), despite relatively low values in samples of Akören, Göçeruşağ 1 and Kuyudere sites (260-2269 ppm; av.1327 ppm). The total ion current chromatograms of the saturated hydrocarbon fractions of five samples are shown in Fig. 7.

In the studied samples, $n$-alkanes are the dominant peaks of gas chromatograms, and unimodal distribution is observed (Fig. 7a). The relative abundance of the oddnumbered ones in the $n$-alkanes in the $\mathrm{C}_{11}-\mathrm{C}_{35}$ range and the $n-\mathrm{C}_{29}$ and $n-\mathrm{C}_{31}$ components is dominant (Table 5 and Fig. 7a). In particular, long chain $n$-alkanes $\left(n-\mathrm{C}_{27}\right.$ to $n$ $\mathrm{C}_{32}$ ) are typically found in the highest relative abundances in low-rank coals in Turkey (Yalçın Erik and Ay 2010, 2013; Ünal et al. 2014; Kara-Gülbay 2015). High molecular weight $\left(>n-\mathrm{C}_{27}\right)$ straight chain lipids, which are 

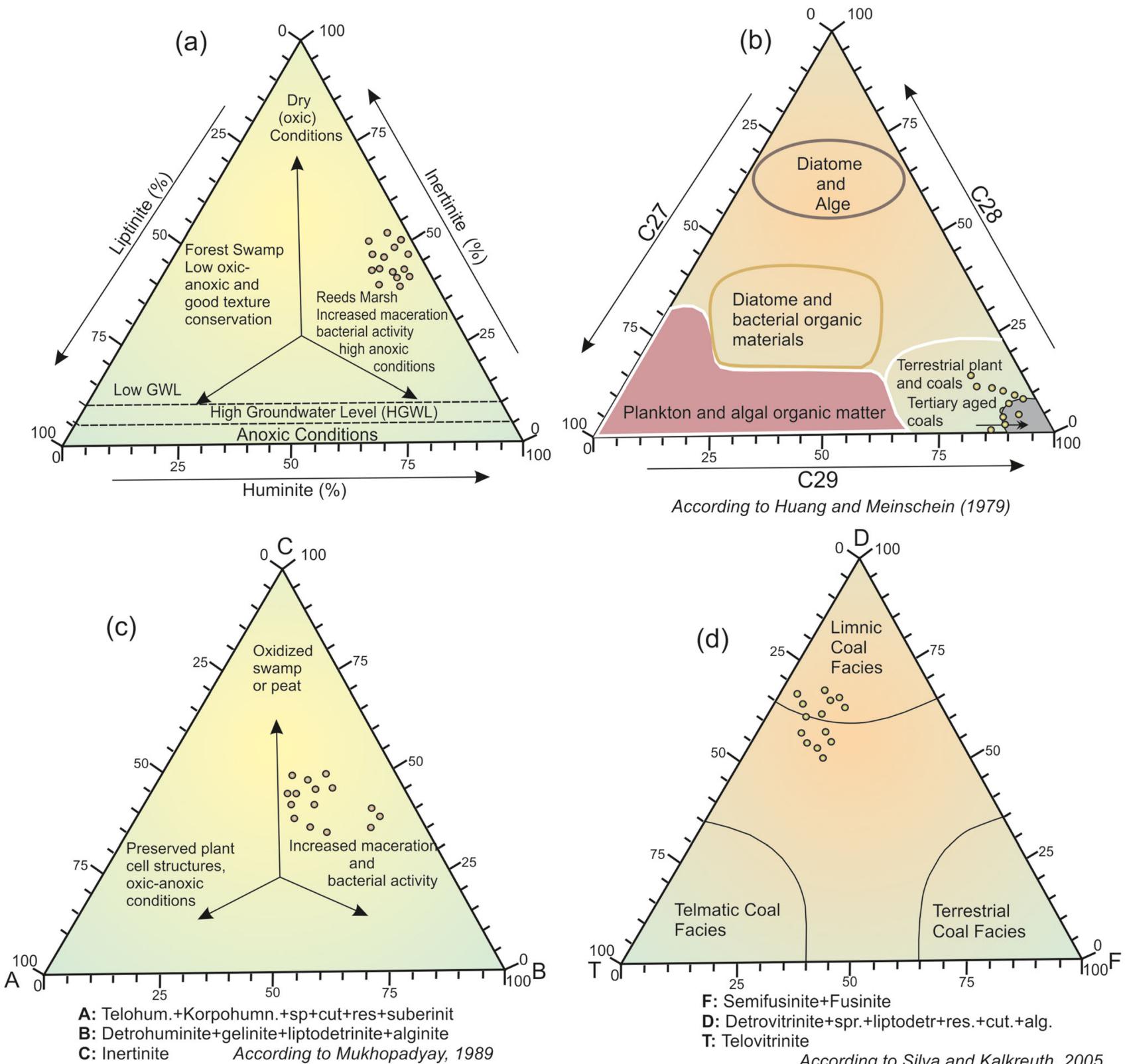

Fig. 6 Ternary diagrams expressing the sedimentation conditions and the organic matter type of the investigated coals

the main component of plant waxes, are characteristic biomarkers for higher terrestrial plants (plant wax) (Eglinton and Hamilton 1967). These data bring about a controversial issue in terms of the formation of long-chain $n$-alkanes from vascular plants, but they are suitable for the immature character of organic matter (Peters and Moldowan 1993). Low molecular weight $n$-alkanes $\left(<\mathrm{C}_{20}\right)$ consisting of major algae and microorganisms are found in very low relative ratios, such as $1 \%$ of total $n$-alkanes (Peters et al. 2005) (Fig. 7). The intermediate molecular weight $n$-alkanes $\left(n-\mathrm{C}_{21-25}\right)$, which are reported to be originated from aquatic macrophytes (Ficken et al. 2000), are found in studied samples in proportions between $19 \%$ and $29 \%$ relative to total n-alkane concentrations (Table 5 and Fig. 7a). The acyclic isoprenoids pristane $(\mathrm{Pr})$ and phytane $(\mathrm{Ph})$ are present in the saturated hydrocarbon fractions of all samples in low concentrations (Pristane; $0.09 \%-0.97 \%$, and phytane; $0.12 \%-0.54 \%$ ) (Table 5, Fig. 7a).

\subsubsection{Sterane and terpane compounds}

Detailed biomarker characteristics have been used to discern source input of organic matter, maturation degree and 
Table 4 Total organic carbon (TOC) and Rock-Eval pyrolysis results of the studied samples

\begin{tabular}{|c|c|c|c|c|c|c|c|c|c|c|c|c|c|c|}
\hline Coal section & Sample No. & TOC & S1 & $\mathrm{S} 2$ & $T_{\max }$ & $\mathrm{HI}$ & OI & PI & $\mathrm{S} 2 / \mathrm{S} 3$ & PY & QI & BI & $R_{\mathrm{O}}(\%)$ & $R_{\mathrm{O} 2}(\%)$ \\
\hline \multirow[t]{6}{*}{ Parçikan } & PM-03 & 8.61 & 0.57 & 7.83 & 436 & 91 & 97 & 0.07 & 0.94 & 8.40 & 0.98 & 0.07 & 0.38 & 0.69 \\
\hline & P-06 & 40.40 & 0.91 & 46.37 & 417 & 115 & 78 & 0.02 & 1.47 & 47.28 & 1.17 & 0.02 & 0.51 & 0.35 \\
\hline & P-07 & 35.76 & 1.13 & 42.61 & 419 & 119 & 122 & 0.03 & 0.97 & 43.74 & 1.22 & 0.03 & - & 0.38 \\
\hline & P-08 & 37.01 & 2.31 & 84.91 & 417 & 229 & 82 & 0.03 & 2.81 & 87.22 & 2.36 & 0.06 & - & 0.35 \\
\hline & $\mathrm{P}-10$ & 43.02 & 1.28 & 78.46 & 424 & 182 & 72 & 0.02 & 2.53 & 79.74 & 1.85 & 0.03 & 0.39 & 0.47 \\
\hline & P-11 & 30.57 & 1.33 & 22.20 & 413 & 73 & 123 & 0.06 & 0.59 & 23.53 & 0.77 & 0.04 & 0.38 & 0.27 \\
\hline \multirow[t]{2}{*}{ Akören } & A-02 & 30.40 & 1.36 & 23.99 & 416 & 79 & 127 & 0.05 & 0.62 & 25.35 & 0.83 & 0.04 & 0.38 & 0.33 \\
\hline & A-04 & 2.61 & 0.32 & 5.25 & 409 & 201 & 78 & 0.06 & 2.59 & 5.57 & 2.13 & 0.12 & - & 0.20 \\
\hline \multirow[t]{2}{*}{ Kuyudere } & $\mathrm{K}-01$ & 10.14 & 1.26 & 18.79 & 424 & 185 & 55 & 0.06 & 3.34 & 20.05 & 1.98 & 0.12 & - & 0.47 \\
\hline & Akb-2 & 7.48 & 0.77 & 12.32 & 420 & 165 & 64 & 0.06 & 2.56 & 13.09 & 1.75 & 0.10 & - & 0.40 \\
\hline
\end{tabular}

TOC, Total Organic Carbon (\%). S1, the amount of free hydrocarbons in the sample (mg HC/g rock). S2, Remaining HC generative potential (mg HC/g TOC). $T_{\max }$, temperature at which maximum $\mathrm{S} 2$ pyrolyzate can generate $\left({ }^{\circ} \mathrm{C}\right) . \mathrm{HI}$, Hydrogen Index (mg HC/g TOC). OI, Oxygen Index (mg CO $2 / g$ TOC). PI, Production Index (mg HC/g TOC). S2/S3, Hydrocarbon type index. PY, Potential yield (mg HC/g TOC). QI, Quality Index $((\mathrm{S} 1+\mathrm{S} 2) / \mathrm{TOC})$. BI, Bitumen Index (S1/TOC). $R_{\mathrm{o}}(\%)$, Measured vitrinite/huminite reflection value. $R_{\mathrm{O} 2}(\%)$, The vitrinite/huminite reflection value calculated according to Jarvie et al. (2001) $(\%)$

depositional environmental conditions based on the distribution patterns of normal alkanes, isoprenoids, steranes and terpanes (Waples and Machihara 1991; Peters et al. 2005). Biomarker properties of saturated components of Arguvan coal samples are given in Table 6. The main steranes identified in the investigated coal composition are; $\mathrm{C}_{29} 5_{\alpha}$ $(\mathrm{H}), 14_{\alpha}(\mathrm{H}), 17_{\alpha}(\mathrm{H})$-Sterane $(20 \mathrm{R})$ and $\mathrm{C}_{30} 5_{\alpha}(\mathrm{H}), 14_{\alpha}$ $(\mathrm{H}), 17_{\alpha}(\mathrm{H})-(20 \mathrm{R})$ steranes. Terpenoid biomarkers, respectively, according to abundance rates are; $\mathrm{C}_{30}$ tricyclicterpane, homomoretane, $\mathrm{C}_{29} 17_{\beta}(\mathrm{H}), 21_{\alpha}(\mathrm{H})$-30-Normoretane, $\mathrm{C}_{29} 17_{\alpha}(\mathrm{H}), 21_{\beta}(\mathrm{H})$-Norhopane, $\mathrm{C}_{30} \quad 17_{\alpha}(\mathrm{H})$, $21_{\beta}(\mathrm{H})$-Hopane and $\quad \mathrm{C}_{30} \quad 17_{\beta}(\mathrm{H}), \quad 21_{\alpha}(\mathrm{H})$-morethane (Fig. 7b, c).

Arguvan coal samples generally had $\mathrm{C}_{29}>\mathrm{C}_{28}>\mathrm{C}_{27}$ $\alpha \alpha \alpha$ (20R) sterane values, but in the sample K-01, the rates higher than the general average ones were determined, $\mathrm{C}_{28}$ $5 \alpha(\mathrm{H}), 14 \alpha(\mathrm{H}), 17 \alpha(\mathrm{H})$-Sterane (20R). In the sample of A-03, $\mathrm{C}_{27}$ and $\mathrm{C}_{29}, 5 \alpha(\mathrm{H}), 14 \alpha(\mathrm{H}), 17 \alpha(\mathrm{H})$-Sterane (20R) components are in equal proportion, and there are approximate values of $\mathrm{C}_{28} 5 \alpha(\mathrm{H}), 14 \alpha(\mathrm{H}), 17 \alpha(\mathrm{H})$ Sterane (20R) (Table 6). As is common in Tertiary aged coal samples, steranes are more abundant than hopanes (sterane/hopane ratio 1.67-7.79) (Stefanova et al. 2013, Yalçın Erik 2011; Yalçın Erik and Ay 2013). Norhopane/ hopane values generally $>1$, moretane/hopane ratios vary between 0.36 and 2.70 (Table 6). Hopanoids are important constituents of the non-aromatic cyclic triterpenoids of the Arguvan coal samples (Table 6, Fig. 7c). The hopanoid patterns are characterized by the occurrence of $17 \beta, 21 \beta$ (H)-type hopanes from $\mathrm{C}_{27}$ to $\mathrm{C}_{31}$ with the $\mathrm{C}_{28}$ hopane being absent. The ratio of the $17 \beta, 21 \beta(\mathrm{H})-\mathrm{C}_{31}$ hopane to $(17 \beta, 21 \beta(\mathrm{H})+17 \alpha, 21 \beta(\mathrm{H}))-\mathrm{C}_{31}$ hopanes is in the range generally measured in coals $(0.5-0.6$; Table 6$)$. The most probable biological precursor of the hopane derivatives found in the samples are bacteriohopanepolyols (Peters et al. 2005; Singh et al. 2017b).

\section{Discussion and results}

\subsection{Coal type and rank}

Physical and chemical properties of coal are crucial for the classification of coal, quality determination and definition of the potential economic value. Rank (maturity) of the Arguvan coals are specified by reflectance measurement on ulminite (huminite) maceral. The mean random reflectance (Ro) value ranges between $0.38 \%$ and $0.51 \%$ (Table 4 ) across the seams, suggesting that the studied coals have attained 'Brown coal' (German Standard) or 'Sub-bituminous' stage/rank (ASTM) and are of low rank B/C (ISO: $11760,2005)$, and fall in the early diagenetic zone of methane generation (Taylor et al. 1998). It is consistent with other maturation parameters and indicates that the units studied have not matured yet.

\subsection{Evaluation of hydrocarbon generative potential of coals with petrological and biomarker data}

\subsubsection{Type of organic material}

In the Van Krevelen (HI-OI) and HI- $T_{\max }$ diagrams prepared according to the Rock-Eval pyrolysis data of the studied samples, most of the samples were scattered in Type II-III (terrestrial and marine) and Type III kerogen (terrestrial, residual organic matter) in the area (Fig. 8a, b). 
Table 5 Gas chromatographic results and some determined parameters of Arguvan samples

\begin{tabular}{|c|c|c|c|c|c|c|c|c|c|c|}
\hline Sample number parameter & Akb-2 & $\mathrm{K}-01$ & A-02 & A-03 & P-03 & $\mathrm{P}-11$ & $\mathrm{P}-10$ & P-06 & P-07 & P-08 \\
\hline Pristane $(\operatorname{Pr}) \%$ & 0.09 & 0.25 & 0.97 & 0.19 & 0.36 & 0.21 & 0.37 & 0.40 & 0.39 & 0.21 \\
\hline$n-\mathrm{C}_{17} \%$ & 0.26 & 0.42 & 0.42 & 0.73 & 0.15 & 0.33 & 0.31 & 0.33 & 0.29 & 0.17 \\
\hline$n-\mathrm{C}_{18} \%$ & 0.41 & 0.75 & 0.47 & 0.83 & 0.34 & 0.49 & 0.44 & 0.47 & 0.35 & 0.24 \\
\hline Phytane $(\mathrm{Ph}) \%$ & 0.12 & 0.54 & 0.32 & 0.23 & 0.22 & 0.35 & 0.46 & 0.48 & 0.50 & 0.29 \\
\hline $\mathrm{Pr} / n-\mathrm{C}_{17}$ & 0.35 & 0.60 & 0.31 & 0.26 & 0.24 & 0.64 & 1.19 & 1.21 & 1.34 & 1.24 \\
\hline $\mathrm{Ph} / n-\mathrm{C}_{18}$ & 0.29 & 0.72 & 0.68 & 0.28 & 0.65 & 0.71 & 1.05 & 1.02 & 1.43 & 1.20 \\
\hline $\mathrm{Pr} / \mathrm{Ph}$ & 0.75 & 0.72 & 0.68 & 0.28 & 0.65 & 0.71 & 1.05 & 1.02 & 1.43 & 1.20 \\
\hline $\operatorname{Pr} /(\operatorname{Pr}+\mathrm{Ph})$ & 0.62 & 0.46 & 0.89 & 0.44 & 0.45 & 0.38 & 0.43 & 0.55 & 0.75 & 0.45 \\
\hline Short chain $n$-alkanes $\left(<n\right.$ - $\left.\mathrm{C}_{20}\right)(\%)$ & 2.39 & 3.27 & 4.76 & 9.43 & 3.89 & 3.32 & 3.87 & 4.29 & 3.47 & 2.26 \\
\hline Medium chain $n$-alkanes $\left(n-\mathrm{C}_{21}-n-\mathrm{C}_{25}\right)(\%)$ & 11.80 & 14.36 & 9.40 & 17.82 & 15.76 & 7.62 & 13.67 & 14.11 & 10.85 & 11.32 \\
\hline Long chain $n$-alkanes $\left(n-\mathrm{C}_{25}-n-\mathrm{C}_{35}\right)(\%)$ & 85.81 & 82.37 & 85.83 & 72.75 & 80.35 & 89.06 & 82.46 & 81.60 & 85.68 & 86.42 \\
\hline Main $n$-alkane component & $n \mathrm{C}_{31}$ & $n \mathrm{C}_{27}$ & $n \mathrm{C}_{29}$ & $n \mathrm{C}_{31}, n \mathrm{C}_{29}$ & $n \mathrm{C}_{29}$ & $n \mathrm{C}_{29}$ & $n \mathrm{C}_{29}$ & $n \mathrm{C}_{29}$ & $n \mathrm{C}_{29}$ & $n \mathrm{C}_{29}$ \\
\hline$n-\mathrm{C}_{17} / n-\mathrm{C}_{31}$ & 0.01 & 0.05 & 0.02 & 0.07 & 0.02 & 0.02 & 0.03 & 0.04 & 0.02 & 0.01 \\
\hline $\mathrm{CPI}_{25-34}$ & 2.66 & 2.64 & 4.60 & 2.64 & 2.51 & 4.36 & 3.84 & 3.75 & 4.27 & 5.06 \\
\hline $\mathrm{OEP}_{2}$ & 3.20 & 5.62 & 4.78 & 5.63 & 5.60 & 5.84 & 3.69 & 5.56 & 5.20 & 2.82 \\
\hline TAR & 42.88 & 47.21 & 61.64 & 103.25 & 52.24 & 50.22 & 47.11 & 32.67 & 44.58 & 12.28 \\
\hline Wax ratio & 16.92 & 14.52 & 18.67 & 8.6 & 21.06 & 25.40 & 22.40 & 20.40 & 26.78 & 25.47 \\
\hline$P_{\text {aq }}$ & 0.16 & 0.17 & 0.12 & 0.13 & 0.16 & 0.08 & 0.20 & 0.34 & 0.10 & 0.34 \\
\hline$P_{\text {wax }}$ & 0.85 & 0.86 & 0.90 & 0.88 & 0.87 & 0.93 & 0.84 & 0.79 & 0.92 & 0.85 \\
\hline$Q_{\mathrm{w}} / \mathrm{p}$ & 0.55 & 0.79 & 0.72 & 0.60 & 0.76 & 0.72 & 0.84 & 0.84 & 0.75 & 0.78 \\
\hline$Q_{\mathrm{g}} / \mathrm{p}$ & 0.45 & 0.21 & 0.28 & 0.40 & 0.24 & 0.28 & 0.16 & 0.16 & 0.25 & 0.22 \\
\hline Amount of extract (ppm) & 1057 & 1723 & 2269 & 260 & 410 & 1973 & 5202 & 2449 & 3458 & 4143 \\
\hline
\end{tabular}

CPI: $\quad\left(n \mathrm{C}_{25}+\mathrm{C}_{27}+\mathrm{C}_{29}+\mathrm{C}_{31}+\mathrm{C}_{33}\right) /\left(\mathrm{C}_{24}+\mathrm{C}_{26}+\mathrm{C}_{28}+\mathrm{C}_{30}+\mathrm{C}_{32}\right)+\left(\mathrm{C}_{24}+\mathrm{C}_{26}+\mathrm{C}_{28}+\mathrm{C}_{30}+\mathrm{C}_{32}\right) /\left(\mathrm{C}_{26}+\mathrm{C}_{28}+\mathrm{C}_{30}+\mathrm{C}_{32}\right.$ $+\mathrm{C}_{34}$ ) (Bray and Evans 1991)

$\mathrm{OEP}_{2}:\left(n \mathrm{C}_{25}+6 n \mathrm{C}_{27}+n \mathrm{C}_{29}\right) / 4\left(n \mathrm{C}_{26}+n \mathrm{C}_{28}\right)($ Scalan and Smith 1970)

TAR: (Terrestrial/Aquatic Organic matter ratio); $\left(\mathrm{C}_{27}+\mathrm{C}_{29}+\mathrm{C}_{31}\right) /\left(\mathrm{C}_{15}+\mathrm{C}_{17}+\mathrm{C}_{19}\right)$ (Bourbonniere and Meyers 1996)

Wax ratio (WR): $\sum\left(n \mathrm{C}_{21}-n \mathrm{C}_{31}\right) /\left(n \mathrm{C}_{15}-n \mathrm{C}_{20}\right)$ (Zheng et al. 2007)

$P_{\text {aq }}$ : Aquatic plant rate $\left(n \mathrm{C}_{23}+n \mathrm{C}_{25}\right) /\left(n \mathrm{C}_{23}+n \mathrm{C}_{25}+\mathrm{C}_{29}+\mathrm{C}_{31}\right)$ (Ficken et al. 2000)

$P_{\text {wax }}$ : Waxy plant rate $\left(\mathrm{C}_{27}+\mathrm{C}_{29}+\mathrm{C}_{31}\right) /\left(\mathrm{C}_{23}+\mathrm{C}_{25}+\mathrm{C}_{27}+\mathrm{C}_{29}+\mathrm{C}_{31}\right)$ (Zheng et al. 2007)

$Q_{\mathrm{w}} / \mathrm{p}$ : Wood/plant ratio $\left(\mathrm{C}_{27} / \mathrm{C}_{29}\right) /\left(\mathrm{C}_{27}+\mathrm{C}_{29}+\mathrm{C}_{31}\right)$ (Bourbonniere and Meyers 1996)

$Q_{\mathrm{g}} / \mathrm{p}$ : Herb/plant ratio $\left(\mathrm{C}_{31} /\left(\mathrm{C}_{27}+\mathrm{C}_{29}+\mathrm{C}_{31}\right)\right.$ (Bourbonniere and Meyers 1996)

This data is consistent with the results obtained in the petrographical evaluation of coal samples, and shows the dominance of terrestrial organic matter (Table 3, Fig. 6a).

$\mathrm{N}$-alkane and isoprenoid ratios are also used so as to determine the type of organic matter (Peters and Moldowan 1993; Peters et al. 2005). In the studied samples, the $n$ alkane distributions are in the range of $n-\mathrm{C}_{11}$ and $n-\mathrm{C}_{35}$ and the long chain hydrocarbons in the range of $n \mathrm{C}_{25}-n \mathrm{C}_{31}$ are the dominant peaks $(72.75 \%-89.06 \%)$. Medium chain hydrocarbons in the range $n \mathrm{C}_{21}-n \mathrm{C}_{25}$ in the total $n$-alkane composition are $7.62 \%-17.82 \%$ and short-chain $n$-alkanes are found in the ratio of $2.26 \%-9.43 \%$ (Table 5). Shortchain $n$-alkanes are formed from algae and microorganisms and as shown in Table 3; the low rate of alginite in the composition $(1 \%-3 \%)$ is also supported by low hydrogen index and high oxygen index values (Ficken et al. 2000) (Table 4).

The abundance of long-chain $n$-alkanes in immature coals indicates that the primary organic material is terrestrial plant waxes (leaves) rich in cuticular and waxy constituents of long-chain fatty fatty acids, alkanoids and their esters (Eglinton and Hamilton 1967; Tissot and Welte 1984; Zdravkov et al. 2011; Yalçın Erik 2011; Fabianska et al. 2012). According to Schwark et al. (2002), the increase in $n \mathrm{C}_{27}$ and $n \mathrm{C}_{29}$ components in long chain $n$ alkanes indicates high terrestrial plants in forests, and $n \mathrm{C}_{31}$ indicates herbaceous components.

As in the studied examples, high $n \mathrm{C}_{31}$ in the composition $(8.89 \%-18.34 \%$ ) (Fig. 7a) indicates the waxy constituents (wax) of either grass/weed or temperate climate plants such as the ones in Bourgas and Maritza East 

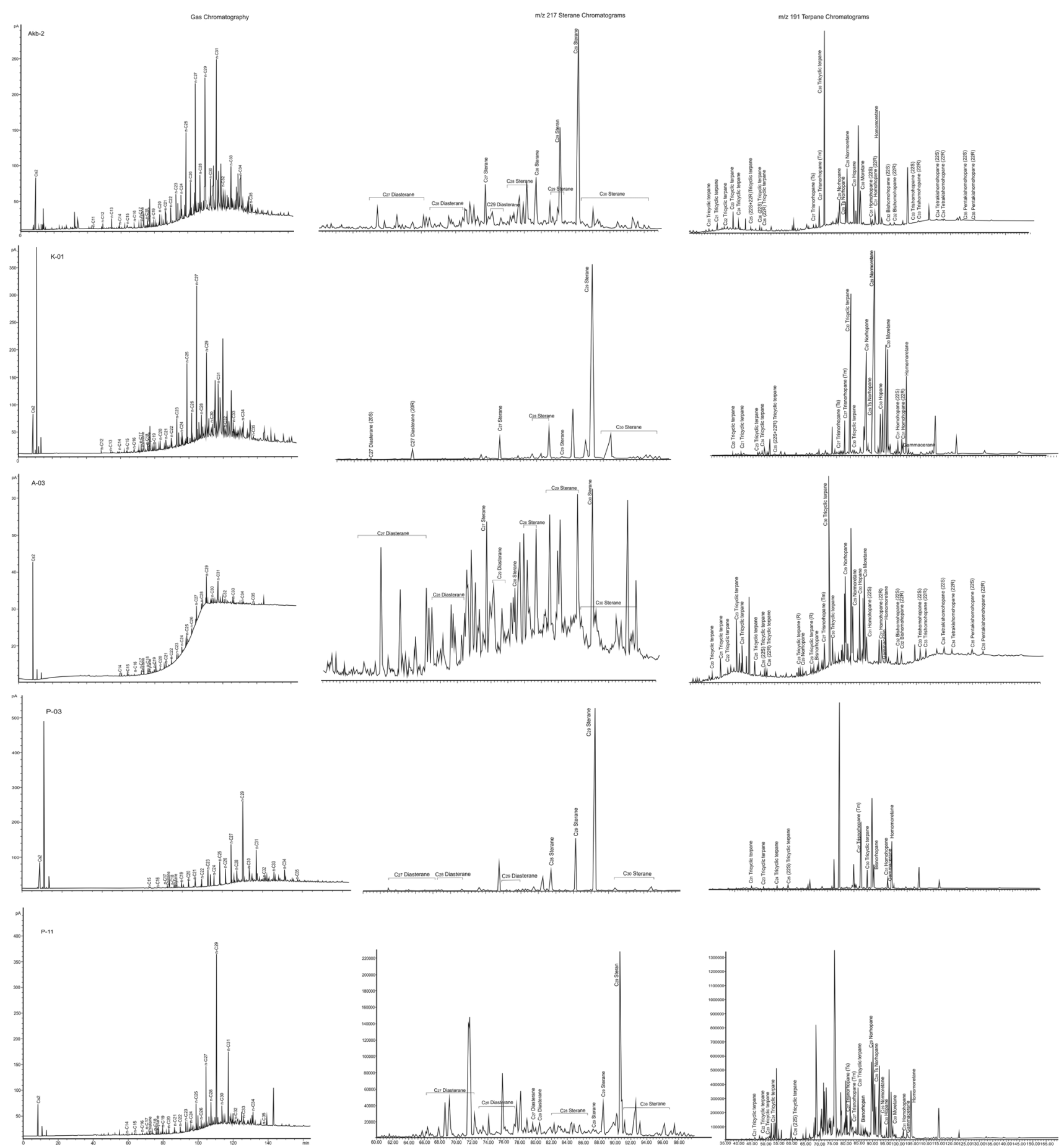

Fig. 7 Gas chromatographic (a) and gas chromatography-mass spectrometry chromatograms (b, c) of the investigated coals

(Bulgaria) coals (Schwark et al. 2002; Bechtel et al. 2005). In varying proportions of the composition, medium-chain n-alkanes are composed of vascular plants, microalgae, cyanobacteria, Sphagnum spp (algae) and aquatic plants (Ficken et al. 2000; Nott et al. 2000).

The biomarker parameters calculated for the Arguvan samples are listed in Table 5. The carbon preference index
(CPI) and Odd-to-even predominance (OEP) may be used as an indicator of the source of the OM (Misra et al. 2020). The carbon preference index $\left(\mathrm{CPI}_{24-34}\right.$; Bray and Evans 1961) values range between 2.51 and 5.06, and indicate higher plant source for the organic matter. In studied samples, even though the values are in accordance with the low rank, the slightly low values could be caused by high 
Table 6 Biomarker parameters calculated from $\mathrm{m} / \mathrm{z}, 217$ and $\mathrm{m} / \mathrm{z}, 191$ mass chromatograms

\begin{tabular}{|c|c|c|c|c|c|c|c|c|c|c|c|}
\hline $\begin{array}{l}\text { Biomarker } \\
\text { parameters }\end{array}$ & & $\mathrm{P}-03$ & $\mathrm{P}-06$ & $\mathrm{P}-07$ & $\mathrm{P}-08$ & $\mathrm{P}-10$ & $\mathrm{P}-11$ & $\begin{array}{l}\text { Akb- } \\
2\end{array}$ & K-01 & $\mathrm{A} 02$ & A03 \\
\hline \multirow[t]{9}{*}{ Steranes } & Sterane $/ 17 \alpha$ Hopane ratio & 7.79 & 3.24 & 3.17 & 3.90 & 1.67 & 2.31 & 5.37 & 4.9 & 2.05 & 1.99 \\
\hline & $\mathrm{C}_{29} 20 \mathrm{~S} /(20 \mathrm{~S}+20 \mathrm{R})$ Sterane ratio & - & - & 0.03 & 1.44 & 0.03 & 0.03 & 0.10 & 1 & 0.07 & 0.47 \\
\hline & $\beta \beta /(\beta \beta+\alpha \alpha)$ Sterane ratio $\left(\mathrm{C}_{29}\right)$ & 0.23 & 0.20 & - & 0.21 & 0.20 & 0.15 & 0.34 & 0.97 & 0.21 & 0.45 \\
\hline & $\mathrm{C}_{28} / \mathrm{C}_{29}$ Sterane ratio & - & 0.27 & 3.53 & 4.57 & 3.65 & 1.78 & 1.87 & 23.07 & 0.92 & 1.06 \\
\hline & $\mathrm{C}_{29} / \mathrm{C}_{30}$ Sterane ratio & 1.51 & 5.24 & 4.31 & 5.21 & 6.46 & 17.78 & 0.67 & 3.27 & 2.67 & 1.43 \\
\hline & $\begin{array}{l}\text { Diasterane/(Diasterane + Regular Sterane) } \\
\quad \text { ratio } 1, C_{27}\end{array}$ & 0.04 & 1.18 & 0.15 & 0.94 & 1.44 & 0.98 & 0.58 & - & 0.55 & 0.96 \\
\hline & $\% \mathrm{C}_{27}$ Sterane ratio & 11.87 & 8.22 & 8.34 & 10.16 & 9.37 & 5.15 & 14.26 & 35.17 & 7.42 & 35.60 \\
\hline & $\% \mathrm{C}_{28}$ Sterane ratio & 9.18 & 6.23 & 6.35 & 10.55 & 7.22 & 4.26 & 16.74 & 51.84 & 6.16 & 29.13 \\
\hline & $\% \mathrm{C}_{29}$ Sterane ratio & 78.94 & 85.55 & 85.31 & 79.28 & 83.41 & 90.60 & 69.0 & 12.03 & 86.43 & 35.27 \\
\hline \multirow[t]{16}{*}{ Terpanes } & $\begin{array}{l}\mathrm{C}_{24} \text { Tetracyclic terpane/ } \mathrm{C}_{26} \text { Tricyclic } \\
\text { terpane }\end{array}$ & 0.71 & 0.21 & 0.38 & 0.31 & 0.26 & 0.31 & 1.02 & 0.25 & - & 0.41 \\
\hline & $\mathrm{C}_{31}$ Homohopane/ $\mathrm{C}_{30}$ Hopane ratio & 0.47 & 1.60 & 0.83 & 0.91 & 1.61 & 0.63 & 0.32 & 0.39 & 0.48 & 0.36 \\
\hline & $\mathrm{C}_{35} /\left(\mathrm{C}_{31}-\mathrm{C}_{35}\right)$ Homohopane Ind. & - & - & - & - & - & - & 0.07 & - & - & 0.08 \\
\hline & Moretane/Hopane ratio & 1.27 & 2.22 & 1.13 & 1.33 & 2.70 & 1.12 & 0.90 & 2.62 & 0.68 & 0.36 \\
\hline & $22 \mathrm{~S} /(22 \mathrm{~S}+22 \mathrm{R})$ Homohopane ratio $\left(\mathrm{C}_{31}\right)$ & - & - & - & - & - & - & 0.42 & - & 0.56 & 0.59 \\
\hline & $T \mathrm{~s} /(T \mathrm{~s}+T \mathrm{~m})$ ratio & - & 0.44 & 0.30 & 0.41 & 0.48 & 0.69 & 0.11 & 0.06 & - & 0.22 \\
\hline & Gammacerane index & 0.06 & 0.37 & 0.27 & 0.35 & 0.42 & 0.40 & - & 0.20 & 0.18 & 0.10 \\
\hline & $\mathrm{C}_{23} / \mathrm{C}_{24}$ Tricyclic terpane ratio & 2.52 & 1.00 & 1.92 & 0.51 & 1.25 & 0.31 & 2.16 & 0.86 & 0.77 & 1.89 \\
\hline & $\mathrm{C}_{22} / \mathrm{C}_{21}$ Tricyclic terpane ratio & 0.46 & 0.74 & 0.41 & 0.51 & 0.88 & 1.14 & 0.41 & - & 1.31 & 0.26 \\
\hline & $\mathrm{C}_{24} / \mathrm{C}_{23}$ Tricyclic terpane ratio & 0.40 & 1.0 & 0.52 & 1.97 & 0.80 & 3.27 & 0.46 & 1.16 & 1.30 & 0.53 \\
\hline & $\mathrm{C}_{27} / \mathrm{C}_{29}$ Tricyclic terpan rate & 0.19 & 0.33 & 0.29 & 0.46 & 0.33 & 0.20 & 0.95 & 0.27 & 0.22 & 0.35 \\
\hline & $C_{25} / C_{26}$ Tricyclic terpane ratio & - & 0.2 & 0.4 & 0.42 & - & - & 0.89 & 0.25 & - & 0.74 \\
\hline & $\mathrm{C}_{23}$ Tricyclic terpane $/ \mathrm{C}_{30}$ Hopane & 0.13 & 0.26 & 0.24 & 0.30 & 0.36 & 0.17 & 0.32 & 0.06 & 0.47 & 0.44 \\
\hline & $\operatorname{ETR}\left(\mathrm{C}_{28}+\mathrm{C}_{29}\right) /\left(\mathrm{C}_{28}+\mathrm{C}_{29}+T \mathrm{~s}\right)$ & 1.0 & 0.89 & 0.90 & 0.82 & 0.86 & 0.70 & 0.98 & - & 1.0 & 0.88 \\
\hline & $T \mathrm{~m} / T \mathrm{~s}$ ratio & 6.99 & 1.30 & 2.31 & 1.42 & 1.10 & 0.46 & 8.37 & 15.22 & 4.40 & 1.52 \\
\hline & Norhopane/Hopane ratio & 1.3 & 4.24 & 3.08 & 3.92 & 5.54 & 11.44 & 0.61 & 2.51 & 1.66 & 1.27 \\
\hline
\end{tabular}

microbial activity on the organic matter (Hunt 1995; Peters et al. 2005; Yalçın Erik and Sancar 2010; Yalçın Erik 2011; Yalçın Erik and Ay 2013; Hos-Çebi and Korkmaz 2013).

However, it is stated in recent studies that $\mathrm{CPI}_{24-34}$ value also affects petrographic composition. For example, in Poland (Konin and Turolszow coals), in the Czech Republic and some coals in Greece, it was observed to be different in organic geochemical evaluations, and $\mathrm{CPI}_{24-34}$ values were also different because of lithotype differences (Siavalas et al. 2009; Zdravkov et al. 2011; Fabianska et al. 2012; Havelcova et al. 2012). In general, the average CPI value of xylitic coals 2.8 , in detritic and 4.2 in detoxylitic coals and fusinitic lignites were found to be $1.88-1.78$ on average (Fabianska et al. 2012). Possible reasons for this can be the changes in the amount of low fatty acid containing mainly $n$-alkanes with a single carbon number in cuticular waxy constituents rather than changes in environmental conditions or maturity (Fabianska et al. 2012).
Odd even preference index (OEP 2, for long-chain n-alkanes) is calculated (OEP $2=1 / 4\left[\left(n \mathrm{C}_{25}+6 n\right.\right.$ $\left.\left.\mathrm{C}_{27}+n-\mathrm{C}_{29}\right) /\left(n-\mathrm{C}_{26}+n-\mathrm{C}_{28}\right)\right]$, Stojanović et al. 2012) in between 1.90 and 2.62. The odd-numbered/even-numbered $n$-alkan ratios (OEP), which are used to determine the organic matter type by using n-alkanes, are between 2.82 and 5.84 in the examined samples (Table 5). The terrigenous/aquatic ratio (TAR; Bourbonniere and Meyers 1996) for the samples varies from 10.67 to 72.5 . The higher ratio $(>1)$ indicates the relative variation in the terrigenous against aquatic input (Peters et al. 2005) and immature sediments composed of terrestrial plants (Bourbonniere and Meyers 1996; Peters et al. 2005).

The Paq determines the input of submerged/floating aquatic macrophytes relative to emergent and terrestrial organic matter. The proxy aqueous (Paq; Ficken et al. 2000) index of the samples varies from 0.24 to 0.35 . In modern plants, these values correspond to the emergent 

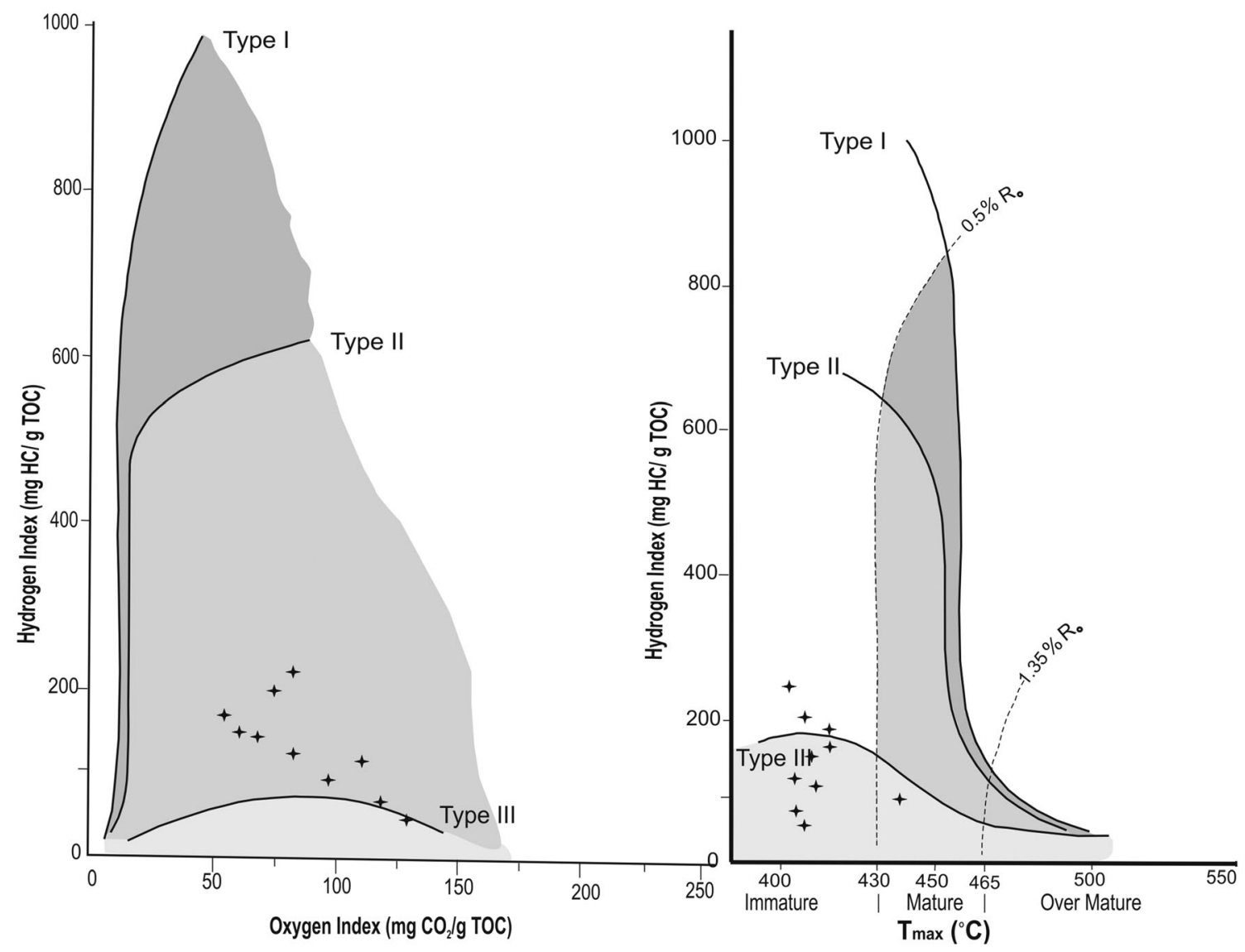

Fig. 8 Van Krevelen (hydrogen index vs. oxygen index) and hydrogen index versus $T_{\max }\left({ }^{\circ} \mathrm{C}\right)$

macrophytes. However, in sediment extracts these values can indicate a mixed organic matter source.

In the studied samples, the $n \mathrm{C}_{17} / n \mathrm{C}_{31}$ ratio (0.02-0.11) (Bray and Evans 1961; Hunt 1995) and degree of wax (Connan and Cassou 1980), $P_{\text {wax }}>P_{\text {aq }}$ and $n \mathrm{C}_{23} /\left(n \mathrm{C}_{27}\right.$ $\left.+n \mathrm{C}_{31}\right)$ values also support the result of domination of terrestrial organic matter. However, although the terrestrial plants are dominant, wood/plant ratio $\left(Q_{\mathrm{w}} / p\right)$ and weed/plant ratio $\left(Q_{\mathrm{g}} / p\right)$ of grassy and grass type short, low cellulose ratio of plants living around the lake show the enrichment (Peters et al. 2005) (Table 5).

The acyclic isoprenoids pristane $\left(P_{\mathrm{r}}\right)$ and phytane $\left(P_{\mathrm{h}}\right)$ are observed in relatively low concentration. The pristane/phytane ratio ranges between 0.28 and 1.43.

In addition, sterane and terpan distributions reflect the types of organic matter (Tissot and Welte 1984; Peters et al. 2005). The presence of $\mathrm{C}_{29}>\mathrm{C}_{28}>\mathrm{C}_{27} \alpha \alpha \alpha$ (20R) sterane in the Arguvan coal samples indicates that mainly high terrestrial plants and later herbaceous plants are dominant in peat formation and small amounts of lacustrine algae are added to the composition (Peters et al. 2005) (Fig. 6b).

However, terpane compositions and paleoenvironment indexes may also indicate the type of organic matter as well as the maturation value (Peters and Moldowan 1993; Peters et al. 2005). The Arguvan coal samples are characterized by the high relative abundance of pentacyclic triterpenes with a maximum abundance of hopanoids. Very low concentrations of $\mathrm{C}_{21}, \mathrm{C}_{23}$ and $\mathrm{C}_{28}$ tricyclic terpane in coal samples from Arguvan, and the high amount of $\mathrm{C}_{19^{-}}$ $\mathrm{C}_{21}$ tricyclic relative to $\mathrm{C}_{23}\left(\mathrm{C}_{19}+\mathrm{C}_{20} / \mathrm{C}_{23}\right.$ tricyclic terpan ratio) refer to the input of terrestrial organic matter (Peters et al. 2005) (Table 6). Furthermore, the presence of the $C_{29}$ Ts $18 \alpha(\mathrm{H})$-Norhopane $\left(\mathrm{C}_{29} \mathrm{Ts}\right.$ ) component (Fig. 7b, c), and $\mathrm{C}_{29} \quad$ Ts $\quad 18_{\alpha}(\mathrm{H})$-Norhopane/ $\left(\mathrm{C}_{29} \mathrm{Ts} 18_{\alpha}(\mathrm{H})\right.$-Norhopane + $\mathrm{C}_{29} 17_{\alpha}(\mathrm{H}), 21_{\beta}(\mathrm{H})$-Norhopane $\left(\mathrm{C}_{29} \mathrm{Ts} / \mathrm{C}_{29} \mathrm{Ts}+\right.$ Norhopane $)$ with ratios, and the presence of $\mathrm{C}_{29} 17_{\beta}(\mathrm{H}), 21_{\alpha}(\mathrm{H})$-30Normoretane and $\mathrm{C}_{30} 17_{\beta}(\mathrm{H}), 21_{\alpha}(\mathrm{H})$-Moretane show that organic matter is of terrestrial origin (Philip and Gilbert 1986). Abundance of hopanoids in the studied samples indicates the considerable contribution from bacterial source to these sediments. Abundance of $17_{\alpha}(\mathrm{H}), 21_{\beta}(\mathrm{H})$-homohopane (R) has been reported previously from low rank coals (Singh et al. 2017a).

This also suggests that these sequences might have been deposited in a more oxic and acidic environment (Źivotić et al. 2014). Extended hopanes are represented by $17_{\alpha}(\mathrm{H})$, $21_{\beta}(\mathrm{H})$-homohopanes (both $22 \mathrm{R}$ and $22 \mathrm{~S}$ epimers), $17_{\beta}(\mathrm{H})$, 
$21_{\beta}(\mathrm{H})$-homohopane and $17_{\beta}(\mathrm{H}), 21_{\beta}(\mathrm{H})$-bishomohopane. Bacteriopolyhopanol, a compound present in the prokaryotic cell membrane is found to be the precursor of homohopanes (Waples and Machihara 1991; Peters et al. 2005).

The identified triterpenoids other than hopanoids include tetra- and pentacyclic compounds with oleanane, and lupane skeletons. Also, they are found to constitute very low amount in the composition of oleanane (Fig. 7c), and this indicates that plant material is denser by gymnospermderived plants rather than angiosperms (Peters et al. 2005). According to all these data, it can be said that terrestrial plants are dominant in the paleo-swamp environment. However, beginning from the reed plants, grasses near the water, herbaceous components near the marsh near the drier forest area, a developing vegetative accumulation, and to a lesser extent, woody components with high cellulose content, and high terrestrial plants and algae were also included in the composition (Peters and Moldowan 1993; Peters et al. 2005).

\subsubsection{Organic maturity}

As a result of the evaluation of Hydrogen Index (HI) and $T_{\max }$ (Mukhopadhyay et al. 1995), most of the samples are suitable for vitrinite/huminite reflection values $\left(R_{\max }\right.$ values $0.38 \%-0.51 \%)$ and indicate the immature stage (Fig. 8b). Production index (PI) which is another maturity parameter obtained by pyrolysis analysis is in the range of 0.02-0.07 and together with the $T_{\max }$ data, and it indicates the diagenesis stage for immature sediments and hydrocarbon generation (Peters 1986; Hunt 1995; Wilkins and George 2002) (Table 4). Besides these data, low extracts of samples, $\beta \beta$ hopans, $17_{\beta}(\mathrm{H})$ trisnorhopane, presence of olefinic components and triterpanes, $\mathrm{CPI}_{24-34}$ values, $\mathrm{C}_{32}$ $22 \mathrm{~S} / 22 \mathrm{~S}+22 \mathrm{R}$ homohopane ratios, $\mathrm{C}_{23}$ tricyclic terpane/ $\left(\mathrm{C}_{23}\right.$ Tricyclic terpane $+\mathrm{C}_{30}$ hopane $) T \mathrm{~s} / T \mathrm{~s}+T \mathrm{~m}$ ratio, moretane/hopane ratio, $20 \mathrm{~S} / 20 \mathrm{~S}+20 \mathrm{R}$ and $\beta \beta / \beta \beta+\alpha \alpha$, diasterane index values also indicate immature phase especially for hydrocarbon formation (Seifert and Moldowan 1986) (Tables 5 and 6).

\subsubsection{Paleo-mire and coal facies characteristics}

Facies analysis, palynology and sedimentological data are widely used in the determination of the coalification process and the characteristics of the depositional environment. The most common used petrological parameters in the paleo-environment and facies assessment of coals are tissue preservation index (TPI) and gelification index (GI), vegetation index (VI) and groundwater effect index (GWI). Changes have been made in this evaluation method by Calder et al. (1991) and Lamberson et al. (1991), in addition, some changes were made for coal with low carbonization degree by Kalkreuth et al. (1991).

Although there is a disagreement among the researchers regarding the interpretation of these data (Moore and Shearer 2003; Sen et al. 2016), TPI/GI and GWI/VI data continue to be used for paleo-depositional interpretation (Kalkreuth et al. 1991; Calder et al. 1991; Kalkreuth et al. 2000; Flores 2002; Siavalas et al. 2009; Singh and Singh 2000; Yalçın Erik 2011; Sia and Wan Hasiah 2012; Singh et al. 2013; Bechtel et al. 2014; Sen et al. 2016; Hoş Çebi and Korkmaz 2013). However, a more accurate interpretation can be obtained by multidisciplinary approaches (Scott 2002; Moore and Shearer 2003).

In Arguvan coal samples, TPI, GI, GWI and VI indices were calculated according to modifications introduced by Kalaitzidis et al. (2004) and Scott (2002) for Miocene lowrank coals. The TPI measures the degree of humification of the peatforming organic matter. A high TPI value $(>1)$ reflects equilibrium between the growth and accumulation of plant materials, rise of the water table, and domination of tree vegetation. A low TPI suggests either predominance of herbaceous plants in the mire or large-scale degradation of plant tissues as a result of advanced humification (Diessel 1992). The TPI also indicates the $\mathrm{pH}$ conditions of palaeomires because in a low $\mathrm{pH}$ conditions, microbial activity is weak and plants can be well preserved, and vice versa. Tissue Protection Index (TPI) value of Arguvan field samples ranged from $0.14 \%$ to $0.33 \%$ (Table 3 ).

The GI is the ratio of gelified versus non-gelified macerals and indicates the wetness in peat-forming environment. High GI value is indicative of a high moisture/water level and higher subsidence rate and vice versa. The gelification index (GI) value in the investigated samples ranges between $0.38 \%$ and $2.86 \%$.

The VI is related to the type of vegetation that dominated the mire. It is dependent on the type of peat-forming plant communities (e.g. trees and bushes). VI generally indicates an aqueous environment in which herbaceous plants develop, as well as an area with woody plants.

Groundwater effect index (GWI) values were between $2.00 \%$ and $8.22 \%$, while vegetation index (VI) values were determined between $0.38 \%$ and $0.82 \%$ (Table 3). This data generally indicates the dominance of herbaceous vegetation in the palaeomire (Kalaitzidis et al. 2004; Silva et al. 2008; Siavalas et al. 2009). This GWI values indicate ombrotrophic hydrological conditions (Fig. 9a).

TPI values are generally low; GWI is greater than 1 and VI is generally less than 1, also gastropod shells with high pyrite content indicate limnotelmatic environment (Fig. 9b). Low TPI and GI values were either dependent on the type of plant material (high angiosperm/gymnosperm ratio) or they developed according to low tissue protection conditions. As determined in the Arguvan coals, medium- 


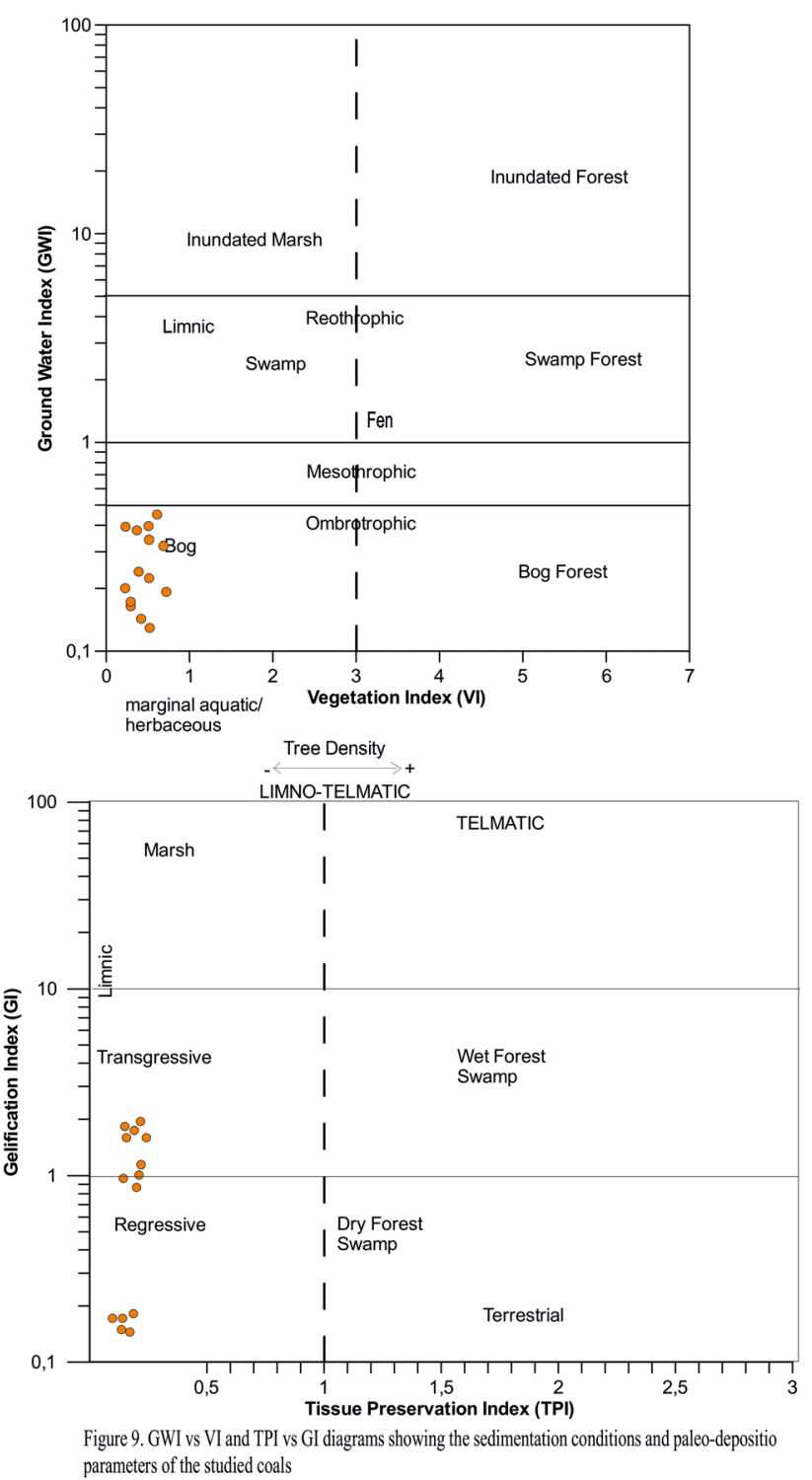

Fig. 9 GWI versus VI and TPI versus GI diagrams showing the sedimentation conditions and paleo-depositio parameters of the studied coals

high GI-GWI values indicate variable water level, and relatively medium-high sulfur content refers to alkaline, calcium-rich waters and changing $P_{\mathrm{h}}$ values (Casagrande 1987; Bechtel et al. 2003). In addition, according to Flores (2002) organic facies characteristics, the coals around Arguvan are rich in herbaceous plants and deposited in a wet forest and dry-wet mixed swamp environment.

In this environment, the water level usually covers the paleotopography and generally suboxic-anoxic conditions prevail. In wet forest facies, humotelinite ratio (ulminite) is abundant, and in mixed marshes, humodetrinites are dominant, and to a lesser extent, resinites and subberinites are accompanied. Abundance of inertinite macerals such as fusinite after humunite maceral group shows fires and decreasing water level in the marshes, thus surface oxidation (Flores 2002). The richness of the studied coals in terms of sporinite and clay minerals also indicates degradation due to reeds and underwater conditions as well as bacterial activity.

The medium-high sulfur content in the coals studied can be explained by the composition of the primary organic material or by marine or brackish water conditions affecting the depositional environment. Framboidal pyrites are related to the presence of sulfate-rich waters, and anaerobic bacterial activity during the formation of peat showed that the paleo temperature value could be between 100 and $125{ }^{\circ} \mathrm{C}$ (Rort, $0.38 \%-0.45 \%$ ) according to the reflection value of Arguvan coals (Boggs 1987).

Isoprenoid and $n$-alkane data of the studied samples are also used in the interpretation of the precipitation medium. For example, the $\mathrm{Pr} / \mathrm{Ph}$ ratio is directly related to the redox conditions of the precipitation medium (Didyk et al. 1978; ten Haven et al. 1987; Tissot and Welte 1984; Peters et al. 2005; Fabianska et al. 2012; Powell et al. 1991). High $P_{\mathrm{r}} /$ $P_{\mathrm{h}}$ ratio $(>3.0)$, oxidized, low rates $(<0.6)$ anoxic, values between 1.0 and 3.0 indicate suboxic conditions (Peters and Moldowan 1993). For example, in coal in SE Asia, it was reported that the $P_{\mathrm{r}} / P_{\mathrm{h}}$ ratio was $>4$ and it showed peat marsh in oxic conditions (Zulkifli et al. 2008). The same situation is laso valid for Pinangah coals (Malaysia) (Alias et al. 2012; Hakimi et al. 2013) and many Tertiaryaged Turkish coal gave similar results (Yalcin Erik and Sancar 2010; Yalcin Erik 2011; Yalcin Erik and Ay 2013; Bechtel et al. 2014; Hoş Çebi and Korkmaz 2013).

$P_{\mathrm{r}} / n \mathrm{C}_{17}(0.26-2.4)$ and $P_{\mathrm{h}} n \mathrm{C}_{18}(0.28-1.43)$ values were found to be similar to Tertiary coal in Bulgaria and Poland (Zdravkov et al. 2011; Havelcova et al. 2012). The $P_{\mathrm{r}} / n \mathrm{C}_{17}$ and $P_{\mathrm{h}} / n \mathrm{C}_{18}$ diagrams indicate oxidation-reduction conditions in the precipitation medium (Fig. 10). Fabianska et al. (2012) indicated the water washing effect of coals and stated that these results in Tertiary aged coal in Poland reflect the alteration effect and do not fully show the environmental characteristics. According to Fabianska et al. (2012), the water washing effect during or after carbonization is characterized by features such as low extract value in organic matter, destruction of methylnaphthalenes and sometimes removal of low carbon number $n$-alkanes. The low levels of $n \mathrm{C}_{17}$ in the organic composition are supported by the low amount of alginite in the petrographic composition, for this type of paleo bog wet, forest-reed bog sedimentation medium (in the lower delta plain) was determined. However, as in the Parcikan coal samples, $P_{\mathrm{r}} / n \mathrm{C}_{17}$ ratios varying generally from moderate to high (greater than 1 or nearly 1 ) are related to coal formation in the continental and limnotelmatic environments. Similar results were obtained in Tertiary aged coal 


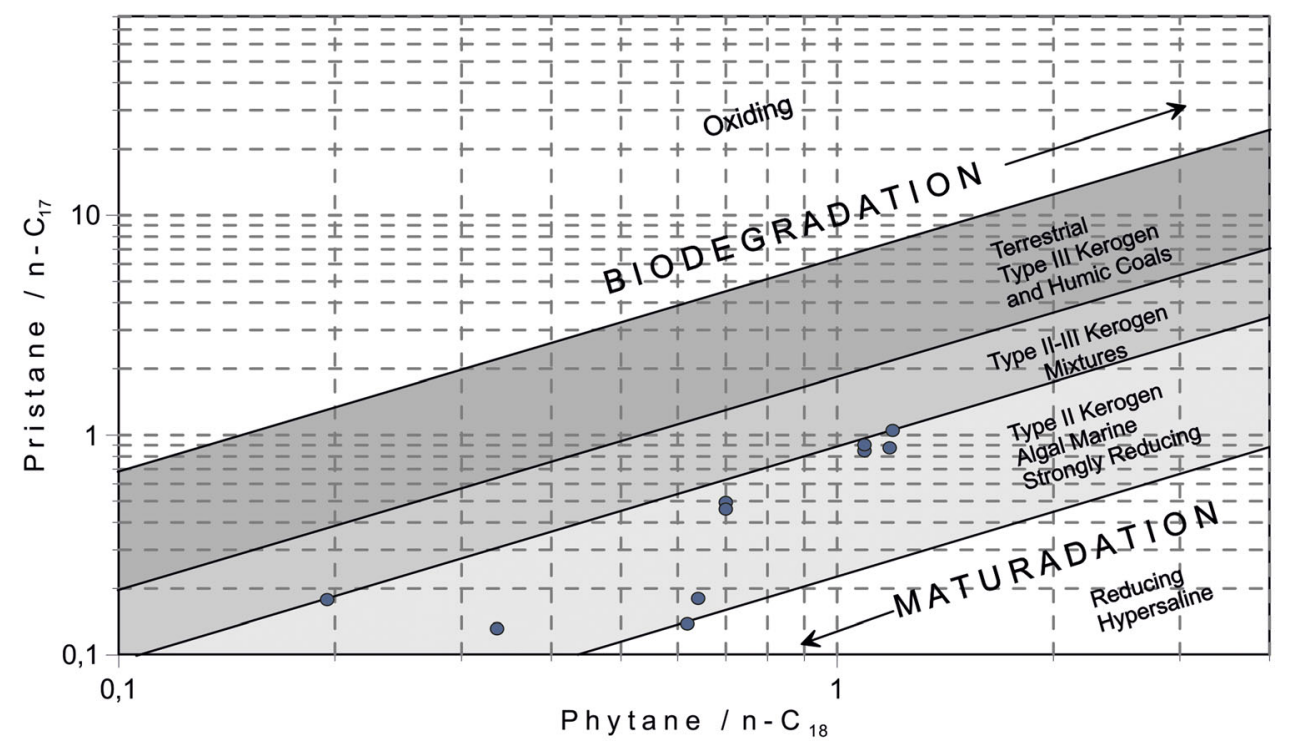

Fig. $10 P_{\mathrm{r}} / n \mathrm{C}_{17}$ versus $P_{\mathrm{h}} / n \mathrm{C}_{18}$ diagrams showing the characteristics of sedimentation environment of the investigated coals $P_{\mathrm{r}} / n \mathrm{C}_{17}-P_{\mathrm{h}} / n \mathrm{C}_{18}$ diagrams

in Sumatra basin (Indonesia) by Amijaya and Littke (2005).

Sterane and terpane data of coals are important to explain the paleoenvironment characteristics (Peters 1986; Peters et al. 2005; Alias et al. 2012). Homohopans are present in all samples of the Arguvan coals, and the decrease in the $17_{\alpha}(\mathrm{H}), 21_{\beta}(\mathrm{H})$-homohopane ratios in the $\mathrm{C}_{31}-\mathrm{C}_{35}$ range is typically observed for clastic facies (Waples and Machihara 1991; Peters and Moldowan 1993) (Fig. 7b, c). The presence of hopanoids indicates the presence of bacterial organisms (Simoneith 1986), which is especially typical of coals in Indonesia (Amijaya et al. 2006)

In Arguvan coals, $\alpha, \beta-\mathrm{C}_{31}$ hopanes are at very low rates and $17_{\alpha}(\mathrm{H}), 21_{\beta}(\mathrm{H})-30$ norhopane dominance is a characteristic for humotelinite rich coals (Amijaya et al. 2006). The hopane content is higher in detritic lignites $(>80 \%)$, increasing the hopane ratio with increasing gelification rate, which generally refers to the increase in ulminite content (Georgakopoulos and Valceva 2000; Sykorová et al. 2005).

$T \mathrm{~m} / T$ s ratios may also reflect paleoenvironment properties; high values indicate oxic conditions during sedimentation (Peters et al. 2005). The high $T \mathrm{~m} / T$ s values determined in the studied samples are consistent with the $P_{\mathrm{r}} / P_{\mathrm{h}}$ ratios and indicate that the swamp formed by atmospheric precipitation (ombrogenous paleomire) is exposed to oxic conditions showing periodic change in the upper part (Ten Haven et al. 1987; Peters et al. 2005). A similar situation was also determined by Amijaya et al. (2006) in coal in Malaysia. However, it is seen that low proportional changes in $T$ s and $T \mathrm{~m}$ values may be related to maseral composition. The highest rates are in the coal rich in humocollinite (Amijaya and Littke 2005; Stojanović et al. 2012; Misra et al. 2020). In addition, high $\mathrm{C}_{29} 17 \alpha(\mathrm{H}), 21 \beta$ (H)-30-Norhopane values accompanying, low " $17 \alpha(\mathrm{H})$ 28,30-Bisnorhopane" deltaic deposition conditions and low rate of marine organic matter doped, refer to sovereign terrestrial organic matter accumulation, and low diasterane/ sterane, low $\mathrm{C}_{23}$ tricyclic terpane/ $\mathrm{C}_{23}$ tricyclic terpane $+\mathrm{C}_{30}$ hopane rates also support this data (Peters et al. 2005).

Also, gammacerans and pregnans are high salinity markers, $\beta \alpha$-Moretane/ $\alpha \beta$-hopane (moretane/hopane) ratio, low $P_{\mathrm{r}} / P \mathrm{~h}$ (Ten Haven et al. 1987), and $P_{\mathrm{r}} / n \mathrm{C}_{17}$ and Tm/Ts ratio and low-high norhopane/hopane ratios also indicate anoxic and refer to the low-moderate salinity conditions (Waples and Machihara 1991; Peters and Moldowan 1993; Hunt 1995; Peters et al. 2005; Alias et al. 2012; Stojanovic et al. 2012).

It can be said that the suboxic-anoxic conditions of Arguvan coals change periodically with high ash and sulfur content, topogenic, eutrophic swamp (in an elevated terrestrial area) and high mineral matter rate. It can also be said that there is an autochthonous-hypotoctonous coal formation that develops in limnotelmatic environment where there is not much intake of epigenetic clastic material. In addition, petrographic data of these coals are drawn in ternary diagrams. In these diagrams, the presence of mixed vegetation in the paleomire environment is indicated (Fig. 6c, d). Besides, the abundance of detrohuminite mixed up with liptodetrinite in some samples indicates significant contribution of reed/sedge vegetation. Appropriate $\mathrm{pH}$ and water-level conditions can be another 
explanation for the good preservation of cell structure. Almost all samples are projected on the lowest part of the Mukhopadhyay's diagram indicating relatively strong anoxic conditions in the northern part of the deposit in comparison to the eastern one; this suggests rather high and relatively stable water table in the palaeomire during peat accumulation (Fig. 6c) (Diessel et al. 2010; Silva et al. 2008).

\subsection{Source rock potential}

As in the examples in the study area, humic coals contain richer organic matter content (generally $<10 \%$ TOC) than conventional oil/gas source rocks, predominantly composed of type III and Type II/III kerogen, and have gas generation potential (Hunt 1995; Wilkins and George 2002; Petersen 2002). However, for Hedberg (1968), Sykes (2001), Petersen (2002) the hydrogen index (HI), which indicates the abundance of hydrogen in coals is more important than the total organic carbon (TOC) value. In general, they stated that values higher than $>200 \mathrm{mgHC} / \mathrm{g}$ (Hunt 1995) are necessary for generation. The TOC values of Arguvan samples evaluated within this scope vary between $2.61 \%$ and $43.02 \%$, hydrogen index (HI) values between 73 and $229 \mathrm{mgHC} / \mathrm{g}$ and $\mathrm{H} / \mathrm{C}$ values between 0.91 and 6.71. In addition, $\mathrm{S} 2 / \mathrm{S} 3$ values are between 0.59 and 3.34 , and production index (PY) is 5.57-87.22. S1 values are between 0.32 and 2.31, and S2 values are between 5.25 and $84.91 \mathrm{mgHC} / \mathrm{gTOC}$. According to these values, it can be said that only P-08 and A-04 samples have gas generative potential (Tissot and Welte 1984; Peters 1986; Hunt 1995; Sykes and Snowdon 2002) (Fig. 11). However, as stated by Killops et al. (1998), the bitumen index of these samples is quite low for species $(\mathrm{BI}>10)$ and removal

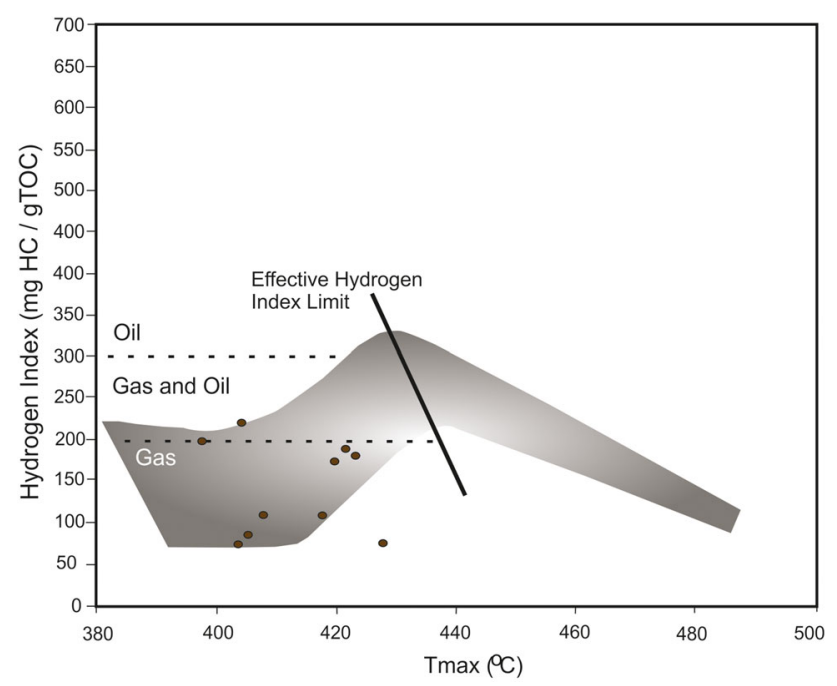

Fig. 11 HI- $T_{\max }$ diagram of Arguvan-Parçikan coals
$(B I>10) \quad(0.02-0.12) \quad($ Table 4). Considering the rank related increase in HI of low-rank coals (Sykes and Snowdon 2002), none of the samples exceed the minimum $\mathrm{HI}$ of $300 \mathrm{mg} \mathrm{HC} / \mathrm{g}$ TOC required for oil generation (Pepper and Corvi 1995) when their thermal maturity reaches the onset of oil expulsion ("effective HI" of Sykes and Snowdon 2002) (Fig. 11).

The hydrocarbon potential in the samples was evaluated mainly by pyrolysis analysis data, and petrological data for coals are also important (Petersen 2002; Fabianska et al. 2012). Generally, the ratio of liptinite macerals $>15 \%$ $20 \%$ has been found to be very important for hydrocarbon generation from coals (Stach et al. 1982; Petersen 2002; Sykes and Snowdon 2002; Wilkins and George 2002; Alias et al. 2012). For the humic coals of the Dong Ho Basin (Vietnam), which offer petrographic and chemical properties similar to Arguvan coals, and the oil window onset for Konin and Turszow coals in Poland are equal approximately to $1.03 \%-1.15 \% R_{\mathrm{o}}$. These coals have been mainly derived from oil and gas (Zdravkov et al. 2011; Fabianska et al. 2012). In Arguvan coals, maturation level is not sufficient for hydrocarbon generation according to biomarker maturity parameters and $T_{\max }$ and $R_{\mathrm{o}}$ values, and thus it was concluded that gas type generation could be possible at higher maturity values.

\section{Conclusions}

Concerning the significance of limited fossil fuel resources of Turkey, lignites/brown coals are of great economic importance as they represent the main source for energy production. A significant number of coal bearing basins with significant coal reserves formed during the Miocene especially in Western Anatolia of Turkey, as a result of different peat-forming conditions. Apart from the economical importance, the hydrocarbon generation potential and geochemical properties of coal-bearing strata have been intensely discussed all around the world. As a result of the floral evolution, especially Cenozoic coals and coaly sediments have higher potential to generate oil compared to older age counterparts.

During this research, the hydrocarbon potential and the paleo-depositional environment characteristics of the lignites from the places around Arguvan in Malatya Tertiary Basin were evaluated based on petrological, bulk organic geochemical parameters and biomarker analysis results. Samples were collected from Parçikan, Akören, Göçeruşağ ${ }_{1}$ and Kuyudere coal areas of Arguvan district. Investigated coaly units are composed of rich carbonated and coaly clay levels in coal, clay, organic matter.

Due to the regional intense tectonics, the coaly sequence is folded, broken, and easily fragmented. This lignites are 
typical humic coals. Calcite bands, pyrite, jarosite, and clay minerals are widely observed in the intermediate levels in the coal units or in veins, lenses, or scattered in the coal vein. The mineralogical composition of the studied samples is dominanted by mineral carbonate and clay (calcite, $4 \%-$ $96 \%$, dolomite, $7 \%$ ). The clay minerals in the composition are illite $(12 \%-76 \%)$, smectite $(21 \%-63 \%)$ and chloride $(11 \%-75 \%)$.

The ash yield of the samples is quite high (avr. 80.81 wt $\%$ ). Total sulfur content is $1.46 \%$, total moisture content $28.69 \%$, volatile matter content $15.45 \%$, and the gross heating value is between 318 and $2027 \mathrm{kcal} / \mathrm{kg}$ (avr, $1001 \mathrm{kcal} / \mathrm{kg}$ ). High values such as $1282-2027 \mathrm{kcal} / \mathrm{kg}$ have been determined only for the Parçikan coal mining area samples. The carbon content in the dry basis determined by elemental analysis is $43.41 \%$ on average, $5.53 \%$ on hydrogen average, $1.23 \%$ on average nitrogen. According to ASTM (1983) standards, Arguvan coals are of low quality and low maturity $\left(R_{\max } \%\right)$, low calorific, high ash, mineral matter and moisture values and potential for industrial use only as domestic fuel, of the type "lower bituminous $\mathrm{B} / \mathrm{C}$ type coal.

The Arguvan coal is dominated by mixed xylitic/attrital and detritic lithotypes and by huminite macerals (gelinite) (avr. 60.29\%) with secondary inertinite macerals (avr. $5.57 \%$ ) and minor liptinite macerals (avr. 5.29\%). Although the coals examined seem physically different from each other, they do not differ greatly as petrographic composition. Local and vertical variations in proportions of huminites and inertinites reflect frequent fluctuations in water levels, periodic flooding, dehydration and burning periods of the paleomire. According to the petrological and organic geochemical characteristics, the paleodepositional environment which formed the investigated coals around Arguvan developed more mixed forest marsh where the herbaceous and reed-crop plants cover wide areas, the water level decreases and the trees are concentrated in more distant areas. Peatification proceeded in a freshwater environment under variable redox conditions, from anoxic to slightly oxic.

Recently, detailed organic geochemical analyses in coal extracts have been used as an effecting tool for assessment of the reconstruction of paleobotanical characteristics and palaeoenvironmental conditions in peatlands during the formation of coal-bearing strata. In the examined samples, the n-alkane distributions are in the range of $n \mathrm{C}_{15}$ and $n \mathrm{C}_{35}$, with long and intermediate chain hydrocarbons being dominant. In addition, TAR, ETR, CPI, $P_{\text {wax }}>P_{\text {aq }}$ and $n-$ $\mathrm{C}_{23} /\left(n \mathrm{C}_{27}+n \mathrm{C}_{31}\right)$ values support the terrestrial organic matter dominance in paleomire. It can be said that suboxic-anoxic conditions are effective during the formation of peat according to $n$-alkane, isoprenoid and biomarker data. The major biomarkers are $\mathrm{C}_{30}$ tricyclic terpane, hopane, homohopane, moretane. In the studied samples, $\mathrm{C}_{29}>\mathrm{C}_{28}>\mathrm{C}_{27}$ steranes indicate the dominance of terrestrial and herbaceous plants, as well as the incorporation of lesser amounts of lacustrine algae. The environment with a high rate of sterane/hopane and a lacustrine or special bacterial activity and a low concentration of pentacyclicterpenes $\left(\mathrm{C}_{32}-\mathrm{C}_{35}\right)$ indicates that biodegradation, and autochthonous/aquatic and allochthonous terrestrial organic materials have accumulated in paleomire during the formation of coals. In XRD and organic petrographical studies, it can be said that the tectonic movements in the swamp are influenced by the appearance of clay minerals and detrohuminites in high order and formation of coal. This situation is also clearly observed in units showing coarse and soft sedimentary deformation in the field.

The total organic carbon (TOC, wt $\%$ ) values of the samples are between 2.61 and $43.02 \%$ and the hydrogen index values are between 73 and $29 \mathrm{mgHC} / \mathrm{g}$ TOC. The high TOC is corroborated by the hydrocarbon yield (S2) indicating excellent source rock generative potential for the samples. Based on HI, the Arguvan-Parçikan coal can be classified as being capable of generating gas/oil $(>200 \mathrm{mg}$ $\mathrm{HC} / \mathrm{g}$ TOC) at higher maturity. Vitrinite reflectance $\left(R_{\mathrm{o}}\right.$, $\%), T_{\max }$ and biomarker ratios show that the organic matter of the studied samples are thermally immature. When all these data are considered together, Tertiary aged coals around Arguvan are have good hydrocarbon generation potential, especially gas, in terms of organic matter type (Type III and Type II/III mixed), organic matter amount ( $>10$ wt\% TOC), however, low liptinitic macerals $(<15 \%-20 \%)$, low hydrogen index $(<200 \mathrm{mg} \mathrm{HC} / \mathrm{gTOC})$ and low thermal maturity values inhibit the hyrocarbon generation.

Acknowledgements This study was supported as CUBAP (Sivas Cumhuriyet University Scientific Research Projects) M-610 Project.

Open Access This article is licensed under a Creative Commons Attribution 4.0 International License, which permits use, sharing, adaptation, distribution and reproduction in any medium or format, as long as you give appropriate credit to the original author(s) and the source, provide a link to the Creative Commons licence, and indicate if changes were made. The images or other third party material in this article are included in the article's Creative Commons licence, unless indicated otherwise in a credit line to the material. If material is not included in the article's Creative Commons licence and your intended use is not permitted by statutory regulation or exceeds the permitted use, you will need to obtain permission directly from the copyright holder. To view a copy of this licence, visit http://creativecommons. org/licenses/by/4.0/.

\section{References}

ISO 7404-5 (2009) Methods for the petrographic analysis of coals d part 5: method of determining microscopically the reflectance of vitrinite. Standards Australia, Level 10, The Exchange Centre 20 
Bridge Street, GPO Box 476, AU-Sydney NSW 2001. www. standards.org.au

Alias FL, Abdullah WH, Hakimi MH, Azhar MH, Kugler RL (2012) Organic geochemical characteristics and depositional environment of the Tertiary Tanjong Formation coals in the Pinangah area, onshore Sabah, Malaysia. Int J Coal Geol 104:9-21

American Society for Testing and Materials (ASTM) (2004) Annual Book of ASTM Standards, vol. 05.06, American Society for Testing and Materials, West Conshohocken, PA, Specifically: ASTM D-2234. Standard Practice for Collection of a Gross Sample of Coal

American Society for Testing and Materials (ASTM) D3174 (2004) Standard method of ash in the analysis sample of coal and coke from coal. Annual Book of ASTM Standards Gaseous Fuels: Coal and Coke vol. 05.06. ASTM, Philadelphia, PA, pp 322-326

American Society for Testing and Materials (ASTM) D3302 (2004) Standard method of total moisture in coal. Annual Book of ASTM Standards, Part 26, Gaseous Fuels: Coal and Coke. ASTM, Philadelphia, PA, pp 352-358

American Society for Testing and Materials (ASTM) D5373, 2004. Standard test methods for instrumental determination of carbon, hydrogen, and nitrogen in laboratory samples of coal and coke. Annual Book of ASTM Standards, Part 26, Gaseous Fuels: Coal and Coke. ASTM, Philadelphia, PA, pp 504-507

American Society for Testing and Materials (ASTM) D5865 (2004) Standard test method for gross calorific value of coal and coke. Annual Book of ASTM Standards 2004. Gaseous Fuels: Coal and Coke vol. 05.06. ASTM, Philadelphia, PA, pp 519-529

Amijaya H, Littke R (2005) Microfacies and depositional environment of Tertiary Tanjung Enim low rank coal, South Sumatra Basin, Indonesia. Int J Coal Geol 261(3-4):197-221

Amijaya H, Schwarzbauer J, Littke R (2006) Organic geochemistry of the Lower Suban coal seam, South Sumatra Basin, Indonesia: palaeoecological and thermal metamorphism implications. Org Geochem 37:261-279

Bechtel A, Gruber W, Sachsenhofer RF (2003) Depositional environment of the Late Miocene Hausruck lignite (Alpine Foreland Basin): insights from petrography. organic geochemistry and stable carbon isotopes. Int J Coal Geol 53:153-180

Bechtel A, Saschsenhofer RF, Zdravkov A, Kostova I, Gratzer R (2005) Influence of floral assemblage, facies and diagenesis on petrography and organic geochemistry of the Eocene Bourgas coal and the Miocene Maritza-East lignite (Bulgaria). Org Geochem 36:1498-1522

Bechtel A, Karayiğit AI, Sachsenhofer RF, İnaner H, Christanis K, Gratzer R (2014) Spatial and temporal variability in vegetation and coal facies as reflected by organic petrological and geochemical data in the Middle Miocene Çayirhan coal field (Turkey). Int J Coal Geol 134-135:46-60

Bechtel A, Karayiğit AI, Bulut Y, Mastalerz M, Sachsenhofer RF (2016) Coal characteristics and biomarker investigations of Dombayova coals of Late Miocene-Pliocene age (Afyonkarahisar-Turkey). Org Geochem 94:52-67

Boggs S Jr (1987) Principles of Sedimentology and Stratigraphy. Macmillan Publishing Company, University of Oregon, New York

Booth MG, Robertson AF, Tasli K, İnan N (2014) Late Cretaceous to Late Eocene Hekimhan Basin (Central Eastern Turkey) as a supra-ophiolite sedimentary/magmatic basin related to the later stages of closure of Neotethys. Tectonophysics 635:6-32

Bourbonniere RA, Meyers P (1996) Sedimentary geolipid records of historical changes in the watersheds and productivities of Lakes Ontario and Erie. Limnol Oceanogr 41:352-359

Bray EE, Evans ED (1961) Distribution of n-paraffins as a clue for recognition of source beds. Geochim Cosmochim Acta 22:2-15
Calder JH, Gibling M, Mukhopadhyay K (1991) Peat formation in a Westphalian B piedmont setting, Cumberland basin, Nova Scotia: implications for the maceral-based interpretation of rheotrophic and raised paleomires. Bull. Soc. Geol. 162:283-298

Casagrande DJ (1987) Sulphur in peat and coal. In: Scott AC (ed) Coal and coal-bearing strata: recent advances. Geological Society Special Publication, London, pp 87-105

Connan J, Cassou AM (1980) Properties of gases and petroleum lipids derived from terrestrial kerogen at various maturation levels. Geochim Cosmochim Acta 44:1-23

Taylor GH, Teichmüller M, Davis A, et al. (1998) Org Petrology. Gebrüder Borntraeger, Berlin

Didky BM, Simoneit BRT, Brassell SC, Eglinton G (1978) Organic geochemical indicators of paleoeoenvironmental conditions of sedimentation. Nature 272:216-222

Diessel CFK (1992) Coal-bearing depositional systems. Springer, Berlin, $\mathrm{p} 721$

Diessel CF (2010) The stratigraphic distribution of inertinite. Int $\mathbf{J}$ Coal Geol 81(4):251-268

Eglinton G, Hamilton RJ (1967) Leaf epicuticular waxes. Science 156:1322-1335

Erdoğan D (2004) Malatya Havzasının Yazıhan kesimindeki Miyosen yaş1 kömürlü kayaçların mineralojik-petrografik ve jeokimyasal incelemesi, Cumhuriyet Üniv. Fen Bilimleri Ens. Yüksek Lisans tezi, 72. s (Unpublished)

Fabiańska MJ, Lewińska-Preis L, Galimska-Stypa R (2012) Changes in organic matter of selected Miocene lignites and embedded sediments caused by microbial desulphurisation. Fuel 94:586-595

Ficken KJ, Li B, Swain DL, Eglinton G (2000) An n-alkane proxy for the sedimentary input of submerged/floating freshwater aquatic macrophytes. Org Geochem 31:745-749

Flores D (2002) Organic facies and depositional palaeoenvironment of lignites from Rio Maior Basin (Portugal). Int J Coal Geol 48:181-195

Georgakopoulos A, Valceva S (2000) Petrographic Characteristics of neogene lignites from the Ptolemais and Servia Basins, Northern Greece. Energy Sources Part A Recovery Util Environ Effects 22(7):587-602

Görür N, Tüysüz O, Şengör AMC (1998) Tectonic evolution of the Central Anatolian Basins. Int Geol Rev 40:831-850

Hakimi MH, Abdullah WH, Sia SG, Makeen YM (2013) Organic geochemical and petrographic characteristics of Tertiary coals in the northwest Sarawak, Malaysia: implications for palaeoenvironmental conditions and hydrocarbon generation potential. Mar Pet Geol 48:31-46

Havelcová M, Sykorová I, Trejtnarová H, Šulc A (2012) Identification of organic matter in lignite samples from basins in the Czech Republic: geochemical and petrographic properties in relation to lithotype. Fuel 99(2012):129-142

Hedberg HD (1968) Significance of high-wax oils with respect to genesis of petroleum. Am Assoc Pet Geol Bull 52:736-750

Hökerek S, Özçelik O (2015) Organic facies characteristics of the Miocene Soma Formation (Lower Lignite Succession-KM2), Soma Coal Basin, western Turkey. Energy Procedia 76:27-32

Hoş-Çebi F, Korkmaz S (2013) Organic geochemistry and depositional environments of Eocene coals in northern Anatolia, Turkey. Fuel 113:481-496

Hunt JM (1995) Petroleum geochemistry and geology. W.H. Freeman and Company, New York

ICCP (1994) The new Vitrinite classification (ICCP System 1994). Fuel. 1998, 77 pp. 349-358

ICCP (1998) The new vitrinite classification (ICCP System 1994). Fuel 77:349-358

ICCP (2001) The new inertinite classification (ICCP System 1994). Sci Technol Fuel Energy 80:459-471 
İçel İ (1988) Malatya-Arguvan Tersiyer Havzası Linyit Prospeksiyonu Raporu. M.T.A. Rap. No: 8377 (yayımlanmamış)

ISO 11760 (2005) Classification of Coals International Standard, pp 1-9

Kalaitzidis S, Bouzinos A, Papazisimou S, Christanis K (2004) A short-term establishment of forest fen habitat during Pliocene lignite formation in the Ptolemais Basin, NW Macedonia, Greece. Int J Coal Geol 57:243-263

Kalkreuth WD, Marchioni D, Calder J, Lamberson M, Naylor R, Paul J (1991) The relationship between coal petrography and depositional environments from selected coal basins in Canada. Int J Coal Geol 19:21-76

Kalkreuth W, Holz M, Kern M, Silva M, Burger H, Lemos de Sousa M, Rodrigues C, Süffert T (2000) The coalbed methane potential of Permian coals in the Paraná Basin of Brazil: preliminary results. In: AAPG Annual Convention, New Orleans, Official Program, American Association of Petroleum Geologists, New Orleans, 9, A69

Kara-Gülbay R (2015) Organic geochemical and petrographical characteristics of coal bearing Oligo-Miocene sequence in the Oltu-Narman Basin (Erzurum), NE Turkey. Int J Coal Geol 149:93-107

Killops SD, Funnell RH, Suggate RP, Sykes R, Peters KE, Walters C, Boudou JP (1998) Predicting generation and expulsion of paraffinic oil from vitrinite-rich coals. Org Geochem 29(1-3): 1-21

Koç-Taşgın C (2011) Seismically generated hydroplastic deformation structures in the Late Miocene lacustrine deposits of the Malatya Basin, eastern Turkey. Sediment Geol 235:264-276

Lafarque E, Marquis F, Pilot D (1998) Rock-Eval 6 applications in hydrocarbon exploration, production, and soil contamination studies. Revue De L'Institut Français Du Petrole 53:4

Lamberson M, Bustin M, Kalkreuth W (1991) Lithotype (maceral) composition and variation as correlated with paleo-wetland environments, Gates Formation, northeastern British Columbia, Canada. Int J Coal Geol 18:87-124

Misra S, Das SK, Varma AK, Mani D, Kalpana MS, Ekblad A, Biswas S (2020) Multi-proxy approach on the hydrocarbon generation perspective of Barjora Basin, India. Mar Pet Geol 112:104108. https://doi.org/10.1016/J.MARPETGEO.2019. 104108

Moore TA, Shearer JC (2003) Peat/coal type and depositional environmentare they related? Int J Coal Geol 56:233-252

Mukhopadhyay PK, Wade JA, Kruge MA (1995) Organic facies and maturation of Jurassic/Cretaceous rocks, and possible oil-source rock correlation based on pyrolysis of asphaltenes, Scotian basin, Canada. Org Geochem 22(1):85-104

Nott CJ, Xiea S, Avsejsa LA, Maddy D, Chambers FM, Evershed RP (2000) n-Alkane distributions in ombrotrophic mires as indicators of vegetation change related to climatic variation. Org Geochem 31:231-235

Okay AI, Tüysüz O (1999) Tethyan sutures of northern Turkey. In: Durand B, Jolivet L, Horvath F, Séranne M (eds) The mediterranean basins: tertiary extension within the Alpine Orogen, vol 156. Geological Society, London, pp 475-515

Önal M (2009) Organic geochemical properties of marine Oligocene unit in the Malatya basin, east Anatolia, Turkey. Energy Sources Part A 31(15):1406-1414

Palmer CA, Tuncalı E, Dennen KO, Coburn TC, Finkelman RB (2002) Characterization of Turkish coals: a nationwide perspective. Int J Coal Geol 60:85-115

Pepper A, Corvi P (1995) Simple kinetic models of petroleum formation. Part I: oil and gas generation from kerogen. Mar Pet Geol 12:291-319

Peters KE (1986) Guidelines for evaluating petroleum source rock using programmed pyrolysis. AAPG Bull 70:318-329
Peters KE, Moldowan JM (1993) The biomarker guide: interpreting molecular fossils in petroleum and ancient sediments. PrenctileHall, Englewood Cliffs

Peters KE, Walters CC, Moldowan JM (2005) The biomarker guide. Biomarkers and isotopes in petroleum exploration and earth history, 2nd edn. Cambridge, pp 475-1155

Petersen HI (2002) A re-consideration of the "oil window" for humic coal and kerogen type III source rocks. J Pet Geol 25:407-432

Philip RP, Gilbert TD (1986) Biomarker distributions in oils predominantly derived from terrigenous source material. In: Leythaeuser D, RullkÖtter J (eds) Advances in organic geochemistry. Pergamon Press, Oxford, pp 73-84

Pickel W, Kus J, Flores D, Kalaitzidis S, Christanis K, Cardott BJ, Crosdale P (2017) Classification of liptinite-ICCP System 1994. Int J Coal Geol 169:40-61

Powell TG, Boreham JG, Smith M, Russell N, Cook JG (1991) Petroleum source rock assessment in non-marine sequence: pyrolysis and petrographic analysis of Australian coals and carbonaceous shale. Org Geochem 17:375-394

Schwark L, Zink K, Lechterbeck J (2002) Reconstruction of postglacial to early Holocene vegetation history in terrestrial Central Europe via cuticular lipid biomarkers and pollen records from lake sediments. Geology 30:463-466

Scott AC (2002) Coal petrology and the origin of coal macerals: a way ahead? Int J Coal Geol 50:119-134

Seifert WK, Moldowan JM (1986) Use of biological markers in petroleum exploration. In: Johns RB (ed) Methods in geochemistry and geophysics, vol 24, pp 261-290

Sen S, Naskar S, Das S (2016) Discussion on the concepts in paleoenvironmental reconstruction from coal macerals and petrographic indices. Mar Pet Geol 73:371-391

Şengör AMC, Yılmaz Y (1981) Tethyan evolution of Turkey: a plate tectonic approach. Tectonophysics 75:181-241

Sia SG, Wan Hasiah A (2012) Geochemical and petrographical characteristics of low-rank Balingian coal from Sarawak, Malaysia: its implications on depositional conditions and thermal maturity. Int J Coal Geol 96-97(22-38):22-38

Siavalas G, Linou M, Chatziapostolou A, Kalaitzidis S, Papaefthymiou H, Christanis K (2009) Palaeoenvironment of Seam I in the Marathousa Lignite Mine. Megalopolis Basin (Southern Greece). Int J Coal Geol 78:233-248

Silva MB, Kalkreuth W, Holz M (2008) Coal petrology of coal seams from the Leão-Butiá Coalfield, Lower Permian of the Paraná Basin, Brazil-implications for coal facies interpretations. Int $\mathbf{J}$ Coal Geol 73(3-4):331-358

Simoneith BRT (1986) Cyclic terpenoids of the geosphere. In: Johns RB (ed) Biological markers in the sedimentary record. Elsevier, Amsterdam, pp 43-99

Singh MP, Singh AK (2000) Petrographic characteristics and depositional conditions of Eocene coals of platform basins, Meghalaya, India. Int J Coal Geol 42:315-356

Singh A, Mahesh S, Singh H, Tripathi SKM, Singh BD (2013) Characterization of Mangrol lignite (Gujarat), India: petrography, palynology, and palynofacies. Int J Coal Geol 120:82-94

Singh A, Shivanna M, Mathews RP, Singh BD, Singh H, Singh VP, Dutta S (2017a) Paleoenvironment of Eocene lignite bearing succession from Bikaner-Nagaur Basin, western India: organic petrography, palynology, palynofacies and geochemistry. Int $\mathrm{J}$ Coal Geol 181:87-102

Singh VP, Singh BD, Singh A, Singh MP, Mathews R, Dutta S, Mahesh VA, Mishra SS (2017b) Depositional palaeoenvironment and economic potential of Khadsaliya lignite deposits (Saurashtra Basin), western India: based on petrographic, palynofacies and geochemical characteristics. Int J Coal Geol 171:223-242 
Stach E, Mackowsky MTh, Teichmüller M et al (1982) Textbook of coal petrology, 3rd edn. Borntraeger, Berlin, p 535

Stefanova M, Kortenski J, Zdravkov A, Marinov S (2013) Paleoenvironmental settings of the Sofia lignite basin: insights from coal petrography and molecular indicators. Int $\mathrm{J}$ Coal Geol 107:45-61

Stojanović K, Zivotic D, Šajnović A et al (2012) Drmno lignite field (Kostolac Basin, Serbia): origin and palaeoenvironmental implications from petrological and organic geochemical studies. J Serb Chem Soc 77(8):1109-1127

Sun HE (1987) Malatya-Arguvan Yöresi Linyit Prospeksiyonu Raporu. M.T.A. Rap. No: 8173 (yayınlanmamış), Ankara

Sykes R (2001) Depositional and rank controls on the petroleum potential of coaly source rocks. In: Hill KC, Bernecker T (eds) Eastern Australasian basins symposium, a refocused energy perspective for the future. Exp Soc Aust Spec Publ, Pet, pp 591-601

Sykes R, Snowdon LR (2002) Guidelines for assessing the petroleum potential of coaly source rocks using Rock-Eval pyrolysis. Org Geochem 33:1441-1455

Sýkorová I, Pickel W, Christanis K, Wolf M, Taylor GH, Flores D (2005) Classification of huminite-ICCP System 1994. Int J Coal Geol 62(1):85-106

Ten Haven HL, de Leeuw JW, Rullkotter J, Sinninghe Damste JS (1987) Restricted utility of the pristane/phytane ratio as a palaeonvironmental indicator. Nature 330:641-643

Tissot BP, Welte DH (1984) Petroleum formation and occurrence. Springer-Verlag, Berlin

TP Enerji Raporu (2015) Ham petrol ve doğal gaz sektör raporu, 2016, $42 \mathrm{~s}$

Tuncalı E, Çiftçi B, Yavuz N, Toprak et al. (2002) Türkiye tersiyer kömürlerinin kimyasal ve teknolojik özellikleri. MTA Genel Müdürlüğü Yayını

Türkmen İ, Aksoy E (1998) Arapgir (Malatya), Çemişgezek (Tunceli) Elazığ dolayındaki Neojen Birimlerinin stratigrafik-sedimentolojik incelenmesi ve bölgesel korelasyonu. TPJD Bülteni 10(1):15-33

Türkmen I, Koç C, Aksoy E, Avşar N, Dinçer F (2004) Arguvan (Malatya) güneyinde yüzeylenen Neojen birimlerinin stratigrafisi ve çökelme ortamları. Geodound/Yerbilimleri 44-45:57-73
Ünal N, Özçelik O (2017) Organic facies characteristics of the coaly units, Şarkikaraağaç Neogene Basin (Isparta/Tyurkey). J Sci Eng Res 4:259-265

Ünal N, Hökerek S, Altunsoy M, Özçelik O, Yalçin Erik N (2014) The biomarker properties and comparisons of Sahinali, Beypazarı and Karapınar (Turkey) Coaly Plio-Miocene Depositions, Energy Procedia, pp 142-149

Waples DW, Machihara T (1991) Biomarkers for geologists-a practical guide to the application of steranes and triterpanes in petroleum geology. AAPG 9:91

Wilkins RWT, George SC (2002) Coal as a source rock for oil: a review. Int J Coal Geol 50:317-361

Yalçın Erik N (2011) Hydrocarbon generation potential and MiocenePliocene paleoenvironments of the Kangal Basin (Central Anatolia, Turkey). J Asian Earth Sci 42:1146-1162

Yalçın Erik N, Ay F (2010) Tersiyer yaşlı Artova ve Zile kömürlerinin (Tokat) organik jeokimyasal özellikleri ve hidrokarbon türetim potansiyelleri. Hacettepe Üniversitesi Yerbilimleri Uygulama ve Araştırma Merkezi Dergisi 31(3):169-190

Yalçın Erik N, Ay F (2013) Organic geochemical characterization and hydrocarbon potential of tertiary coals of the Tokat Province (Central Anatolia, Turkey). Energy Sources Part A 35:991-999

Yalçın Erik N, Sancar S (2010) Relationship between coal-quality and organic-geochemical parameters: a case study of the Erzincan Coal Deposits (Sivas Basin, Turkey). Int J Coal Geol 83:396-414

Yoldaş R (1972) Malatya kuzeyinin jeolojisi ve petrol olanakları. MTA rapor no: 4936 (yayımlanmamıs)

Zdravkov A, Bechtel A, Sachsenhofer RF, Kortenski J, Gratzer R (2011) Vegetation differences and diagenetic changes between two Bulgarian lignite deposits-insights from coal petrology and biomarker composition. Org Geochem 42:237-254

Životić D, Bechtel A, Sachsenhofer R et al (2014) Petrological and organic geochemical properties of lignite from the Kolubara and Kostolac basins, Serbia: implication on grindability index. Int $\mathbf{J}$ Coal Geol 131:344-362

Zulkifli S, Awang SAJ, Kamal RM, Aziz Che (2008) Hydrocarbon generation potential of the coals and shales around the Eucalyptus Campsite area, Maliau Basin, Sabah. Geol Soc Malaysia Bull 54:147-158 